Karadeniz Uluslararası Bilimsel Dergi

Volume: 52, Winter-2021, p. (1-31)

ISSN: 1308-6200 DOI Number: https://doi.org/10.17498/kdeniz.1017830

Research Article

Received: Nov 2, 2021 | Accepted: Nov 16, 2021

This article has been checked for plagiarism.

\title{
BİZANS SANATINDA RHIPIDION (FLABELLUM) VE GEÇ BİZANS DÖNEMİ (13.-15. YÜZYIL) DUVAR RESIMMLERINNDE GÖRÜLEN ÖRNEKLER
}

\section{RHIPIDION (FLABELLUM) IN BYZANTINE ART AND EXAMPLES SEEN ON LATE BYZANTINE (13th-15th CENTURIES) WALL PAINTINGS}

\section{РИПИДА (ПОКЛОННИК) В ВИЗАНТИЙСКОМ ИСКУССТВЕ И ПРИМЕРЫ ИЗОБРАЖЕНИЙ В ПОЗДНЕВИЗАНТИЙСКОЙ (13-15 ВВ.) НАСТЕННОЙ ЖИВОПИСИ}

\section{ÖZ}

\section{Durmuş GÜR* Cahit KARAKÖK**}

Araştırmanın konusunu, Hıristiyan liturjisinde büyük öneme sahip olan rhipidionların (=rhipidia/liturjik yelpaze), geç Bizans dönemi (13.-15. yüzyıl) duvar resimlerinde görülen örnekleri oluşturmaktadır. Rhipidion hakkında ilk yazılı bilgiler, Aziz Clementine'nin metinlerinde (4. yüzyıl sonu) yer almaktadır. 4. yüzyıldan 5. yüzyıla kadar Suriye' deki eski kilise kararnamelerinden derlenen Apostolik Anayasalar'da, rhipidionların liturjideki önemi hakkında bilgilere yer verilmiştir. 500'lerde bir liturji ayini sırasında, sunağın iki yanında sembolik altı kanatlı temsili kıyafetler giyen diyakonların ellerinde rhipidionların bulunduğu, Pseudo Dionysos'un Ecclesiastica Hierarchica eserinde anlatılmaktadır. 6. yüzyılın başına tarihlendirilen bir diptikonda da hakkında bilgiler yer alan rhipidionların ilk defa kumaş, deri, ahşap, tavus kuşu tüyü, parşömen ve keten gibi çeşitli malzemelerden yapıldığ 1 bilinmektedir. İlk kullanıldığında liturjik eşyalardan (artos, kalis, haç, kutsal kitap) böcek ve tozları uzaklaştırmaya yarayan rhipidionlar sonrasında liturjinin parçası haline gelmiştir. Daha sağlam olması için madeni örneklerden yapılan rhipidionlar, geç Bizans dönemine kadar liturjinin parçası olarak kullanılmış, günümüzde de kiliselerde kullanılmaya devam etmektedir. Liturjide bir elinde rhipidion diğer elinde ise buhurdan tutan din adamları dışında ellerinde rhipidion taşıyan melek-diyakonlar, ayinde ön sıralarda yer almaktadır. Tek başına yer alabildiği gibi birden fazla rhipidionun da ayinde bulunabileceği tespit edilen örneklerle kanıtlanmıştır. Din adamları rhipidionları, uzun metal ya da ahşap saplar yardımıyla ayine katılanların görebilmesi amacıyla yukarıda tutmaktadır. Bir yüzünde sembolik figürlerin yer alabildiği gibi iki yüzünde de betimlenen sembolik tasvirler (haç, kherub, seraph) ile yazıtlar, rhipidionların üslup ve ikonografik

\footnotetext{
* ORCID: 0000-0002-9945-8825 Dr. Öğr. Üyesi, Karabük Üniversitesi, Safranbolu Şefik Y1lmaz Dizdar Meslek Yüksekokulu, Geleneksel El Sanatları Bölümü, Karabük / Türkiye. durmusgur@gmail.com

** ORCID: 0000-0001-9201-4810 Arş. Gör., Necmettin Erbakan Üniversitesi, Sosyal ve Beşeri Bilimler Fakültesi, Sanat Tarihi Bölümü, Konya / Türkiye. cahitkarakok@ gmail.com
} 


\section{Durmuş GÜR - Cahit KARAKÖK}

zenginliğini gösterir. Erken Bizans dönemine ait Riha ve Stuma hazinelerindeki (6. yüzyıl) metal rhipidionlarla benzer form ve özellikte rhipidionların geç Bizans dönemine kadar kullanıldığı, günümüz de kullanılmaya devam ettiği belirlenmiştir. Erken Bizans döneminden geç Bizans dönemine kadar liturjik eserlerin dışında minyatür, ikona ve duvar resimlerinde tasvir edilen rhipidionların, 11. yüzyıla tarihlendirilen duvar resimlerinde kullanılmış örneklerinin tespit edilmesi üzerine, 13.-15. yüzyıl arasına tarihlendirilen kilise duvar resimlerindeki tasvirleri kronolojik olarak incelenmiş, form, üslup ve ikonografik özellikleri açısından karşılaştırmalı olarak değerlendirilmiştir.

Anahtar Kelimeler: Flabellum, Kilise, Liturji, Rhipidion, 13.-15. Yüzyıl.

\section{ABSTRACT}

The subject of the research is the samples of the rhipidions (=rhipidia / liturgical fan), which have a great importance in the Christian liturgy, in the wall paintings of the Late Byzantine Period (13th-15th century). The first written information about the Rhipidion is in the texts of St. Clementine (end of the 4th century). The Apostolic Constitutions compiled from the old church decrees in Syria from the 4th to the 5th centuries included information about the importance of rhipidions in liturgy. It is described in Pseudo Dionysus' Ecclesiastica Hierarchica, during a liturgical rite in the 500s, that deacons wearing symbolic six-winged clothing on either side of the altar had rhipidions in their hands. It is known that rhipidions, which have information about it in a dipticon dated to the beginning of the 6th century, were made from various materials such as fabric, leather, wood, peacock feathers, parchment and linen for the first time. Apart from the independent examples made of various materials, it is known that the rhipidion is depicted on book covers, on the kiborium and on the altars, and in many other places. These materials turned into metal works with the early Byzantine period and were enriched with precious stones, liturgical and iconographic elements over time. When first used, rhipidions, which were used to remove insects and dust from liturgical objects (artos, kalis, cross, holy book), later became part of the liturgy. Rhipidions, which are made of metal material to be stronger, were used as part of the liturgy until the late Byzantine period and continue to be used in churches today. In liturgy, apart from the clergy holding a rhipidion in one hand and a insence burners in the other, angel-deacons holding rhipidion in their hands are at the forefront of the ritual. It has been proven with the determined examples that more than one rhipidion can be found in the ritual as well as alone. The clergy hold the rhipidions up with the help of long metal or wooden handles so that those who attend the ritual can see them. Symbolic figures (cross, cherub, seraph) and inscriptions on both sides show the stylistic and iconographic richness of the rhipidions. It has been determined that metal rhipidions which are similar in terms of style and features with the Riha and Stuma treasures (6th century) were used until the late Byzantine period and continue to be used today. It is seen that from the early Byzantine period to the late Byzantine period, rhipidions were depicted in miniatures, icons and wall paintings, apart from liturgical works. In this study, the depictions of the Rhipidions on the church wall paintings dated between the 13th and 15th centuries were examined chronologically and evaluated comparatively in terms of form, style and iconographic features.

Keywords: Flabellum, Church, Liturgy, Rhipidion, $13^{\text {th }}-15^{\text {th }}$ Centuries.

\section{АННОТАЦИЯ}

В данной работе предметом исследования являются образцы рипид (= рипидия / литургических разновидностей), имеющих большое значение в христианской литургии, в настенных росписях поздневизантийского периода (13-15 вв.). Первые 


\section{Bizans Sanatında Rhipidion (Flabellum) ve Geç Bizans Dönemi...}

письменные сведения о рипиде встречаются в текстах святой Клементины (конец 4 в.). Апостольские конституции, составленные на основе старых церковных указов в Сирии с 4 по 5 века, включали информацию о важности рипид в литургии. В книге Псевдо-Дионисия Ареопагита «О церковной иерархии» описывается, что во время литургического обряда в 500-х годах дьяконы, носившие символические шестикрылые одежды по обе стороны от алтаря, держали в руках рипиды. Известно, что рипиды, информация о которых имеется в диптиконе, датируемом началом VI в, впервые были изготовлены из различных материалов, таких как ткань, кожа, дерево, павлиньи перья, пергамент и лен. Помимо самостоятельных образцов, изготовленных из различных материалов, известно, что рипида изображалась на книжных переплетах, кибориумах, алтарях и на многих других предметах. Уже с раннего византийского периода эти материалы уступили место изделиям из металла и со временем стали укарашаться драгоценными камнями, литургическими и иконографическими элементами. Первоначально рипиды использовались для удаления насекомых и пыли с литургических предметов (артос, калис, крест, священная книга), однако позже они стали частью литургии. Рипиды, которые для большей прочности были сделаны из металла, использовались как часть литургии до позднего византийского периода и продолжают использоваться в церквях сегодня. В литургии, помимо духовенства, держащего рипиды в одной руке и кадильницы в другой, ангелы-дьяконы, держащие рипиды в руках, находятся в авангарде ритуала. На конкретных примерах было показано, что более одной рипиды всегда можно найти в ритуале или по отдельности. Священнослужители держат рипиды с помощью длинных металлических или деревянных ручек, чтобы те, кто присутствовал на ритуале, могли их увидеть. Символические фигуры (крест, херувим, серафим) и надписи с обеих сторон демонстрируют стилистическое и иконографическое богатство рипид. Было установлено, что металлические рипиды, сходные по стилю и характеристикам с сокровищами Риха и Стума (6 в.), использовались до позднего византийского периода и продолжают использоваться сегодня. Очевидно, что с ранневизантийского периода до позднего византийского периода рипиды изображались в миниатюрах, иконах и настенных росписях, помимо литургических произведений. В данном исследовании изображения рипид на церковных настенных росписях 13-15 вв. были изучены в хронологическом порядке и прошли сравнительную оценку с точки зрения формы, стиля и иконографических особенностей.

Ключевые Слова, s. поклонник, церковь, литургия, рипида, 13-15 вв.

\section{GíRiș}

Paten, buhurdan ve kalis kadar öneme sahip olan rhipidion, Yunanca'da Rhipidia ve Rhipidion, Latince'de Flabellum, Almanca'da Flabellum, Ermenice'de K'šoc', İngilizce ve Fransizca'da Flabellum, İspanyolca'da Flabellum ve Flabello, Türkçe'de ise Liturjik Yelpaze olarak adlandırılmaktadır (Wessel, 1971, S. 550-555; Von Fürstenberg, 1979, S. 157-192; Kroos and Wirth, 1991, S. 1a; Snelders and Immerzeel, 2004, s. 116; Greenwood, 2015, s. 141). Latince'de Flabella (çoğul), Flabellum (tekil) olarak adlandırılır $^{1}$ (Tribe, 2018, s. 1). Bizans döneminde kiliselerde liturjinin parçası olan

\footnotetext{
${ }^{1}$ Çalışmada, üslup birliği olması amacıyla Yunanca olan rhipidion adı tercih edilmiştir. Çalışma kapsamında bize yardımcı olan Dr.Öğr.Üyesi İlker Mete Mimiroğlu, Doç. Dr. Meryem Acara Eser ve Виталий Прудников (Vitaly Prudnikov)'a teşekkür ederiz.
} 


\section{Durmuş GÜR - Cahit KARAKÖK}

rhipidion, Akdeniz çevresindeki yerleşimlerde erken Bizans döneminden itibaren liturjide yaygın olarak kullanılmıştır (Mango, 1991, s. 1790-1791).

Rhipidionların, Hıristiyanlığın çok ötesinde eski zamanlardan beri dini törenler, soylu ya da yönetici kişilerin hizmetinde kullanıldığı bilinmektedir ${ }^{2}$. Doğu ve Batıdaki kiliselerde kullanılan liturjik yelpazeleri (Wessel, 1971, s. 550-555; Von Fürstenberg, 1979, s. 157-192) diğerlerinden ayırt etmek amaciyla bunlara rhipidion (liturjik yelpaze) adı verilmiş ve liturjiye dahil edilmiştir ${ }^{3}$ (Kroos and Wirth, 1991, s. Ia). Hıristiyanlıkta onursal kullanımının yanında liturjik kullanımıyla öne çıkan rhipidionlardan (Tribe, 2018, s. 1), Hıristiyan kilisesi tarafından çok kısa sürede benimsenen rhipidionların, yaygınlaşmasını kolaylaştırmak amacıyla ilk kullanımlarının Havariler tarafından olduğu iddia edilmiştir. Piskopos Suarez, bu durumu Aziz James'e atfederek görüşlerini desteklemeye çalışmıştır. Rhipidionların ilk kullanımları ise adaklardan hemen sonra ve kutsama duasından önce, iki diyakozun, sunağın iki yanında beklediğini belirten Apostolik Anayasalar üzerinden açıklanmıştır (Rhead, 1910, s. 87). Bazı araştırmacılar tarafından erken kullanımlarının Yahudilere ait sinagoglar olduğu iddia edilse de köken olarak Pagan tapınaklarında dini açıdan kullanıldığı bilinmektedir (Rhead, 1910, s. 87). Aziz Clementine'nin (4. yüzyıl sonu) metinlerinde bahsedilmektedir (Snelders and Immerzeel, 2004, s. 116). Kuzey Afrika'da Ruspe Piskoposu Fulgentius'un (468-533 ya da 462-527) öğrencilik günlerinde, palmiye yapraklarından rhipidion yaptığı bilinmektedir. Başrahip olduğu dönemde görevli olduğu manastırda bu tür eşyaların üretimine büyük önem verdiği bilinen din adamının, bunları hangi amaç doğrultusunda kullandığı belirtilmemektedir (Von Fürstenberg, 1979, s. 161). Latin kiliselerinde rhipidionların erken dönemlerden itibaren benimsenerek kullanıldığına yönelik birçok kanıt mevcuttur. Papa Agapetus'un 535 yılındaki metinlerinde, sunak üzerinde rhipidionun kullanıldığı belirtilmektedir (Rhead, 1910, s. 88). Roma imparatorluğunun nihai olarak dağıldığı dönemden Haçlı Seferleri'ne kadar olan dönemde Avrupa'da rhipidionların kullanımının yasaklandığ 1 bilinmektedir (Rhead, 1910, s. 94-95).

Erken 6. yüzyıla tarihlendirilen bir diptikonda rhipidionlar hakkında bilgiler bulunmaktadır. Erken uygulamalarında deri, tavus kuşu tüyü, parşömen, ahşap ve ketenden yapılmış rhipidionların yerini zamanla madeni örnekler almıştır (Kroos and Wirth, 1991, s. IVA1-5, Mango, 1991, s. 1790-1791, Tribe, 2018, s. 1). Çeşitli malzemelerden yapılmış erken Bizans dönemine tarihlendirilen iki madeni rhipidionun dışında, kitap kapakları, kiborium, altarların üzeri ve daha birçok yerde rhipidionlarınn tasvir edildiği bilinmektedir (Von Fürstenberg, 1979, s. 159).

Madeni örneklerden bazıları değerli taşlarla bezenmiştir, Hildesheim Rhipidionu (1132-1140) madeni rhipidionlara örnektir (Kroos and Wirth, 1991, s. Abb. 6). İlk yapımlarındaki malzeme çeşitliliği, doğada rahat bulunan malzemelerin tercihiyle açıklanmaktadır (Vikan, 1979, s. 617). Kiliselerde ilk defa liturjik eserler ile din adamlarından zararlı böcek ve tozları uzak tutmak amacıyla kullanıldığı belirlenmiştir (Tribe, 2018, s. 1). 13. ve 14. yüzyıla ait iki ayrı metinde, rahiplerin rahatsız olmaması için rhipidionların kullanıldığının belirtilmesi, liturjik eserler kadar din adamlarının da toz ve böcekler karşısında rhipidionlarla korundukları anlaşılmaktadır (Kroos and Wirth, 1991, s. IIA1). İlk örneklerde böcekleri ortamdan uzaklaştırmak ve havayı temizlemek amacıyla kullanıldığı ifade edilen rhipidionlar zamanla liturjinin parçası haline gelmiş, sembolik unsurlarla zenginleştirilmiştir (Snelders and Immerzeel, 2004, s. 116; Kessler, 2012, s. 1).

\footnotetext{
${ }^{2}$ Bizans Ortodoks Kilisesinde liturji ve liturjik eserler için bakınız; (Acara, 1998, s. 183-201)

${ }^{3}$ Yelpazenin ortaya çıkışı, tarihi çağlardan itibaren kullanımı ve modern uygulamaları için bakınız; (Rhead, 1910, s. 1-271).
} 


\section{Bizans Sanatında Rhipidion (Flabellum) ve Geç Bizans Dönemi...}

Günümüzde özellikle Batı kiliselerinde tüyden yapılmış örneklerinin dışında daha birçok malzemeden yapılan rhipidionlar liturjide kullanılmaktadır (Tribe, 2018, s. 1). Karolenj dönemi (9. yüzyıl) rhipidionu ve Sirbistan Banja Aziz Nikolas Kilisesi gümüş rhipidionunun (1559-1560) üzerindeki yazıtlar, yukarıda ifade edilen rhipidionların işlevini açıklamakta son derece önemlidir (Šakota, 2004, s. 133; Kessler, 2012, s. 3-4). Erken Bizans döneminden itibaren liturjide büyük öneme sahip olan rhipidionların, kiliselerde sembolik seraph ve kherub melekleri gibi giyimli diyakonlar tarafından taşınmaktadır (Vikan, 1979, s. 617).
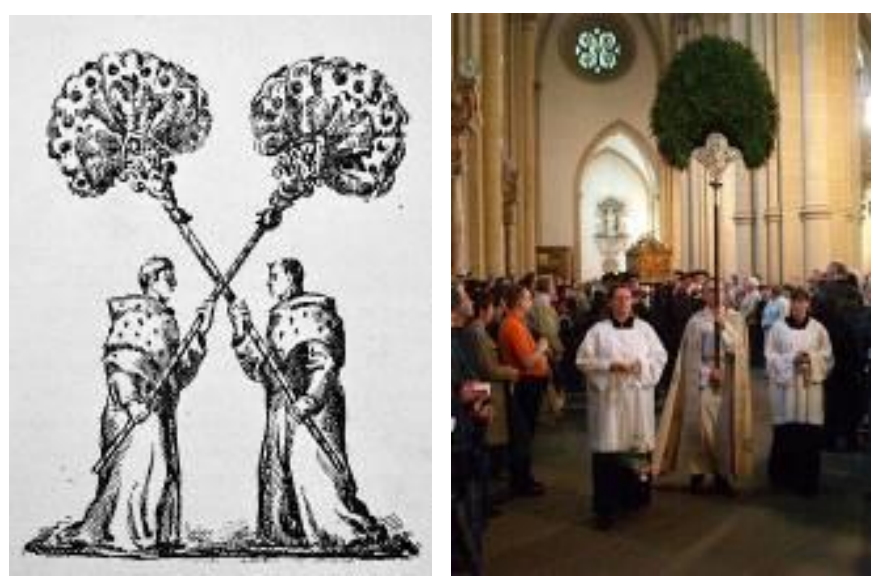

Resim 1a-b. Tavus Kuşu Tüyünden Yapılmış Rhipidionlar (Tribe, 2018, s. 1)

Dönem kaynakları, kutsal kitaplar ve bilim insanlarının çalışmalarında, rhipidionların kullanım aşamaları ve üzerlerindeki tesvirler hakkında bilgi edinmek mümkündür. Bunların tespiti yapılarak kronolojik olarak sunulmuş, çalışma kapsamında ise asıl amacında 13.-15. yüzyıl duvar resimlerindeki rhipidionların form, bezeme ve tasvir özellikleri incelenerek gelişim çizgisi belirlenmeye çalışılmış, dini yapılarda nerelerde ve hangi kompozisyonlarda bezendiği, üslup ve ikonografik özellikleri açısından incelenmiştir.

Kutsal Kitap'ta Eski Ahit Sandığı'nın genel özellikleri sunulurken Keruv adındaki meleklerden bahsedilmektedir (Çıkış, 25, s. 17-22) ${ }^{4}$. Kutsallığıyla bilinen bu meleklerin, erken Bizans dönemiyle birlikte rhipidionlar üzerinden tasvir edilmeye başlanmış, Eski Ahit Sandı̆̆ı'ndaki melekleri geride bırakacak derecede öne çıktığ1 ifade edilmektedir (Woodfin, 2010, s. 310-311). Kiliselerde sunak (altar) üzerinde göksel varlıkların yer aldığı rhipidionları sallayan din adamları

\footnotetext{
4 "Saf altından bir Băğşlanma Kapağı yap. Boyu iki buçuk, eni bir buçuk arşın olacak. Kapağın iki kenarına dövme altından birer Keruv yap. Keruvlar'dan birini bir kenara, öbürünü öteki kenara, kapakla tek parça halinde yap. Keruvlar yukarı doğru açık kanatlarıyla kapağı örtecek. Yüzleri birbirine dönük olacak ve kapağa bakacak. Kapă̆ı sandı̆̆ın üzerine, sana vereceğim taş levhaları ise sandiğın içine koy. Seninle orada, Levha Sandığı'nın üstündeki Keruvlar arasında, Bağışlanma Kapağı'nın üzerinde görüşeceğim ve İsrailliler için sana buyruklar vereceğim”" (Çıkış, 25: 17-22).
} 


\section{Durmuş GÜR - Cahit KARAKÖK}

eşliğinde kutsal ilahiler söylenirken ${ }^{5}$, rhipidionlar meleklerin koruyuculuğu gibi teolojik ve sembolik gücü yanında işlevsel özelliğiyle de zararlı etkileri liturjik eserlerle insanlardan uzaklaştırdığına inanılmaktadır (Vikan, 1979, s. 617). Kiliselerde ve ayinlerde kullanılan rhipidionların büyük boyutlu olanları, Katolik kiliselerinde Papalar tarafindan taşınmakta (Tribe, 2018, s. 1), liturji sırasında ayine eşlik etmektedir (Mango, 1991, s. 1790-1791). 4. yüzyıldan 5. yüzyıla kadar olan dönemde Suriye'deki eski kilise kararnamelerinden derlenen Apostolik Anayasalar'da rhipidionların liturjideki yeri hakkında önemli bilgilere yer verilmiştir (Kroos and Wirth, 1991, s. IIA1). 500'lerde bir liturji ayini sırasında, sună̆ın iki yanında sembolik altı kanatlı temsili kıyafetler giyen diyakonların ellerinde rhipidiların bulunduğu, Pseudo Dionysos'un Ecclesiastica Hierarchica'sinda anlatılmaktadır (Snelders and Immerzeel, 2004, s. 116). Günümüze ulaşan en eski rhipidionun 577 yllına tarihlendirilen, Suriye Kaper Karaon Hazinesi'ndeki gümüş rhipidion olduğu belirtilmektedir (Mango, 1991, s. 1790-1791).
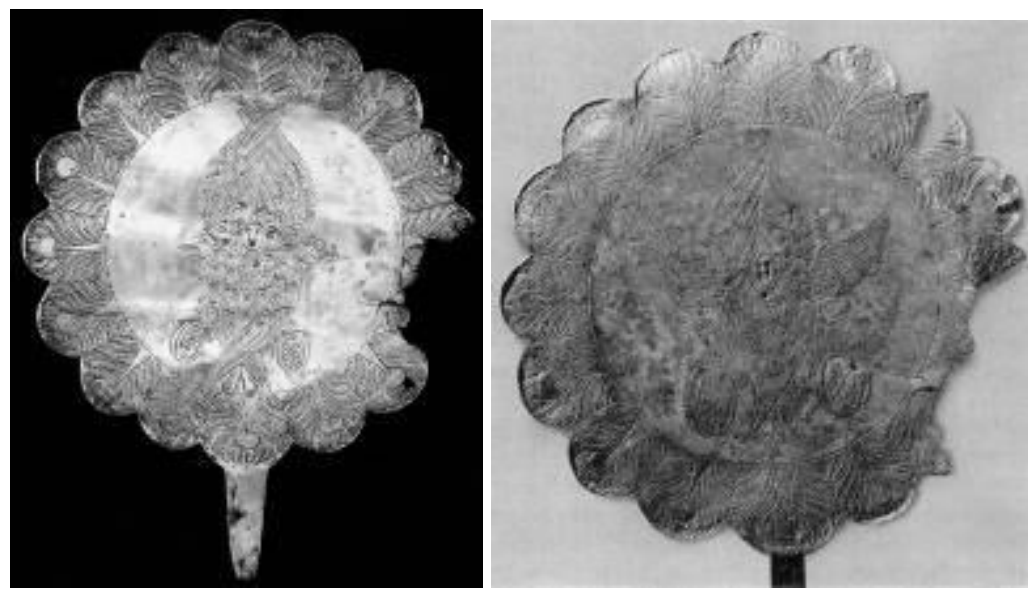

Resim 2a-b. Riha Rhipidionu-Tetramorph, İst. Ark. Müz. (sol) ve Stuma Hazinesi Rhipidionu-Kherub, Washington (565-578) (sağ) (Kroos and Wirth, 1991, s. Abb. 1a-b, Doğan ve Ünser, 2011, s. 2015, Res. 3-4)

Suriye Kaper Karaon Hazinesi'ndeki gümüş rhipidion (577), kenarlar1 dilimli bordürlerden oluşan disk şeklindedir. Günümüzde İstanbul Arkeooji Müzeleri'nde yer alan rhipidion, 30.9 x $25.5 \mathrm{~cm}$ ölçülerindedir. Sağında küçük parçası eksik olan rhipidionu, 16 tavus kuşu tüyü şeklinde dilimli bir bordür çevreler. Bordürün içleri tavuş kuşu tüyü şeklinde bezenmiştir. Ön ve arka yüzlerinde benzer bir düzenleme görülür. Alttaki metal dil, ahşap asaya monte

\footnotetext{
5 “Kral Uzziya'nın öldüğü yıl yüce ve görkemli Rab'bi gördüm; tahtta oturuyordu, giysisinin etekleri tapınağı dolduruyordu. Üzerinde Seraflar duruyordu; her birinin altı kanadı vardı; ikisiyle yüzlerini, ikisiyle ayaklarını örtüyor, öbür ikisiyle de uçuyorlardı. Birbirlerine şöyle sesleniyorlardı: "Her Şeye Egemen RAB Kutsal, kutsal, kutsaldır. Yüceliği bütün dünyayı dolduruyor.” (Yeşeya, 6: 1-3).
} 


\section{Bizans Sanatında Rhipidion (Flabellum) ve Geç Bizans Dönemi...}

etmek için kullanılmıştır (Vikan, 1979, s. 617). Ortada kherub ve seraph ya da meleklerle donatılan birçok rhipidion bulunurken bu örnekte seraph yer almaktadır. Liturjik metinler, rhipidionun ayin sırasında Diyakon tarafindan taşındığını belirtmektedir (Mango, 1991, s. 1790-1791).

II. İznik Konsili'nde (787), meleklerin salt ruhsal yapısının tasvir edilmesi üzerine önemli konular tartışılmış ve onların tasvirine yönelik bazı problemler ele alınmıştır. Meşrulaştırılan II. İznik Konsili'nde (787) melekler kendi başlarına, kutsal görünüşlerine göre tasvir edilebilecekleri belirtilmiştir. Bu dönem sonrasında rhipidionların üzerinde yoğun olarak melek tasvirlerine yer verilmiş, kiliselerde ise melek-diyakonlar tarafindan taşınmaya başlanmıştır (Gillette, 2018, s. 30). Patrik Germanus (8. yüzyıl başı) tarafindan yazılan İstanbul (Konstantinopolis) liturjisinde rhipidionlar hakkında bilgilere yer verilmiştir. Ekklēsiastikē Historia'da rhipidion ve diyakon alayının altı kanatlı, çok gözlü ve yüksek konumda melekler kılığında nasıl göründükleri anlatılmaktadır. Bu durum dünyevi şeylerin göksel varlıkları taklit edilerek oluşturulduğunu göstermektedir. Büyük Giriş’te insanların eylemi uyumlu hale getirilmiş ve göksel ayinlerin sembolü olan aynalı yüzeye sahip rhipidionlar, üzerlerindeki tasvirler ve kullanım aşamaları kapsamında süreçte gelişimini tamamlamıştır (Pentcheva, 2016, s. 11). 8. yüzyıldan itibaren madeni örneklerin dışında çeşitli alanlarda görülen rhipidionların, epitaphion ve duvar resimleri başta olmak üzere birçok etnoğrafik eser üzerinde tasvirine rastlamak mümkündür (Ballian, 2004, s. 133; Djuric, 2014, s. fig. 11; Woodfin, 2015, s. 25, fig. 8; Gillette, 2018, s. 34, Resim 4).

Patrik Germanos (Erken 8. yüzyıl), İstanbul (Konstantinopolis) Liturjisi'nde göksel varlıkların dünyevi yansımaları hakkında bilgilere yer vermiştir ${ }^{6}$. Enkarnasyona proleptik açıdan paralellik yansıtmak amacıyla rhipidionlarla diyakonların altı kanatlı melekler (seraph) şeklinde donatılması kararlaştırılmıştır. Büyük Giriş’te kutsal ile insanların arasında uyumu gösteren uygulamalar, melek düzenlemelerinin yanında dualarla ayine güç katmaktadır (Pentcheva, 2014, s. 15). Büyük Giriş'te okunan Cherubikon (Kherubik İlahi / $\chi \varepsilon \rho o v \beta ı$ ı̀ $\varsigma$ v̌ $\mu v o \varsigma)$, sembolik ilahi olmanın yanında, ayin sırasında Tanrı tahtının çevresinde toplanan melekleri temsil eden ifadelere yer vermektedir. Üç defa kutsal ilahiyi söylemek için sembolik kherubimlerin liturjide yerini aldığı bilinir. Rhipidionlar ile diyakonların üzerindeki kherubim taklidi kıyafetlerin doğrudan bununla bağlantılı olduğu bilinmektedir (Schroeder, 2008, s. 42). İlahiler eşliğinde sallanan ve üzerlerinde sembolik melek tasvirlerine sahip olan rhipidionların, ayin sırasında kutsal alanla birlikte ayine katılanların ruhunu kötülüklerden arındırdığına inanılır (Kessler, 2012, s. 6). Ruhu temizlediği belirtilen rhipidionların üzerindeki kherubların, terminolojik açıdan ellerinde asa ve kılıç taşıdıkları da bilinmektedir (Schroeder, 2008, s. 42).

9. yüzyıldan itibaren rhipidionların dini mülkiyeti, yazılı metinlerle desteklenmektedir. 10. yüzyıl öncesine tarihlendirilen birçok dini metin ve din adamlarına ait yazılarda, Doğu kiliselerinde sadece rhipidiondan sorumlu

\footnotetext{
${ }^{6}$ Germanos'un İstanbul Liturjisi'nde geçen rhipidia ve göksel varlıklar için bakınız; (Meyendorff, 1984, s. 94-95).
} 


\section{Durmuş GÜR - Cahit KARAKÖK}

diyakonların denetiminde rhipidionların liturjide kullanıldığı anlatılır (Kroos and Wirth, 1991, s. IIA1). Kilise kaynaklarında rhipidionların 1200'lerden itibaren liturjilerdeki geçit törenlerinde kullanıldığı aktarılmaktadır (Kroos and Wirth, 1991, s. IIA3). Demetrios Gemistos, 1380'lerde diataxiste, İstanbul (Konstantinopolis) Ayasofya Kilisesi'ndeki liturjide ayin sirasında rhipidionun seramoniye dahil oluşunu şöyle anlatmaktadır;

“.......tören dini liderin öncülügüunde gerçekleşir. Sonra omophorion ile castrensis gelir. Patrik ya da ikinci Diyakon, sonra rhipidiayı taşlyan diyakonlar, onlarla birlikte kutsal ekmek taşlyan diyakon ve onun arkasında diğer eşyalar taşıyanlar gelir. Seramoniler ve dualar eşliğinde liturji gerçekleşir" (Betancourt, 2015, s. 498).

Melek tasvirli rhipidionların, İkonoklazma dönemi (726-842/843) sonrasında, resim sanatında görülen canlanmayla birlikte kiliselerde yaygın olarak kullanılmaya başlandığı ifade edilmektedir (Betancourt, 2015, s. 505-506). 12.-13. yüzyıla tarihlendirilen metinlerde, rhipidionların sunaklarda geçici olarak kurulduğu ya da ayin sonrasında taşınarak korunma altına alındığı yönünde bilgiler bulunur (Kroos and Wirth, 1991, s. IIC-IID). Kiev'deki Ayasofya Kilise (11. yüzyıl), Havariler Komünyonu tasvirlerinde, sunağın iki yanında ellerindeki rhipidionları sunak üzerine dayamış melek-diyakonlar, rhipidionların liturji sırasında sunağa kurulan/yerleştirilen örnekleri çağrıştırmaktadır (Kriza, 2017, s. 99, fig. 6). Metz Kathedrali’nde (1105) özel günlerde sunağın nasıl hazırlanması gerektiğini belirten dini metinlerde, rhipidionun sunakta yer aldığı aktarılmıştır. Salisbury Katedrali (1214) kayıtlarında ikisi ahşap saplara sahip rhipidilar hakkında bilgilere yer verilmektedir (Kroos and Wirth, 1991, s. IIC-IID). Duvar resimlerinde görmeye alıştığımız rhipidionların, sadece İsa ile bağlantılı resimlerde tasvir edilmediği belirlenmiştir. Anna, Meryem, Havariler ya da soylu kişilerin de tasvirlerinde rhipidiaların tasvir edildiği görülmektedir. Örneğin İtalya Roma'da Santi Quattro Coronati Kilisesi yakınlarındaki Santi Silvester Oratory'deki (1246) freskoda, kline üzerinde uzanan imparatorun başında, elinde rhipidion tutan bir mabeynci/eşlikçi, klinenin ayak ucunda ise Petrus ve Pavlus tasvir edilmiştir. Buradaki temsili rhipidionun kullanımı ilginçtir. Rhipidionun yüzeyinde dini tasvir görülmemesine rağmen, kralın uzandığ 1 klinenin ayak ucundaki havarilerin elleriyle O'nu işaret etmeleri ve Pavlus'un elindeki kapalı kutsal kitap, tasvirin dini gücünü yansitmaktadır (Von Fürstenberg, 1979, s. 176).

13.-15. yüzyıl kiliselerinde, apsis, bema ve kubbede görmeye alıştığımız dini ve liturji konulu tasvirlerde, melek ya da melek-diyakonların ellerindeki rhipidionların, 1453 sonrasında da, Yunanistan, Balkanlar ve Avrupa ülkeleri başta olmak üzere geç tarihli birçok kilisenin duvar resimlerinde tasvir edildiği bilinir. Yunanistan Athos Dağı Dochiariou Manastırı (1568), Göksel Liturji (Betancourt, 2015, s. 505, fig. 8), Yunanistan Athos Dağ1 Büyük Lavra Manastır1 (1560), Göksel Liturji (Betancourt, 2015, s. 506, fig. 9) gibi daha birçok kilisenin duvar resimleri buna örnektir. 


\section{Bizans Sanatında Rhipidion (Flabellum) ve Geç Bizans Dönemi...}

\section{Geç Bizans Dönemi Duvar Resimlerinde Rhipidionlar}

Erken Bizans döneminden itibaren rhipidionların yüzlerinde birçok sembol ve melek (kherub ve seraph) tasvir edilmiştir. Suriye Kaper Karaon Hazinesi (577), İstanbul Arkeoloji Müzesi, Dumbarton Oaks Koleksiyonu, New York Brooklyn Müzesi'ndeki rhipidionların yüzlerinde de melekler yer almaktadır. Sembolik tasvirler gibi Tiflis'teki Gürcü Güzel Sanatlar Müzesi'ndeki rhipidion (10.-11. yüzyıl) tetrafoil şeklindedir ve rhipidionun ön yüzünde melek bulunmaktadır (Snelders and Immerzeel, 2004, s. 116). Erken Bizans dönemi duvar resimlerinde rhipidionlara ait herhangi bir resim günümüze ulaşmamıştır. Duvar resimlerindeki ilk örneklerin 11. yüzyıla ait olduğu ileri sürülse de bazı araştırmacılar bu konuya şüpheyle yaklaşmakta, daha çok ilk örnekleri 12 . yüzyıl sonrasına tarihlendirmektedir (Kroos and Wirth, 1991, s. IIA1). İncelemelerimiz neticesinde, ilk rhipidionların, 11. yüzyıla tarihlendirildiği tespit edilen Makedonya ve Ukrayna örnekleriyle desteklenmiştir. Makedonya Ohrid Ayasofya Kilise (11. yüzyıl), apsisteki Havariler Komünyonu duvar resminde, sunak üzerindeki kiborionun iki yanındaki melek-diyakonların ellerinde, üç dişli yaba benzeri bir rhipidion tasvir edilmiştir. Buradaki rhipidionların tüyden yapılmış olabileceği düşünülür. Ayrıca Kiev, Ayasofya Kilise (11. yüzyıl), apsisteki Havariler Komünyonu mozaik kompozisyonunda, üzerinde kiborion yer alan altarın iki yanındaki melekdiyakonlar, ellerindeki rhipidionları, sunağın üzerine dayamış şekilde tasvir edilmiştir. Ellerindeki rhipidionlar, 13.-14. yüzyıllarda Yugoslavya kiliselerinde yaygın olarak tasvir edilen, köşeleri yarım daire şeklinde genişletilmiş örneklerle aynı forma sahiptir (Kriza, 2017, s. 93, 98-99, fig. 1, 5-6; Acara-Eser, 2020, s. 77).

Liturjik eşyaların dışında kiliselerdeki duvar resimleri ve mozaiklerde birçok rhipidion tasvirleri görülmektedir. Kiliselerde apsis, bema, kubbe başta olmak üzere naos ve narteks duvarlarındaki din ve liturji ile bağlantılı resimlerde rhipidionlar tasvir edilmiştir. Havariler Komünyonu, İsa'nın Ölümü, Meryem'in Ölümü (Koimesis Meryem) ve daha birçok ikonografik duvar resminde mabeynci/eşlikçi, melekler ya da melek-diyakonların ellerinde rhipidionlar bulunmaktadır. Mar Hananina Manastırı yakınındaki Kırk Şehitler Kilisesi Kütüphanesi'nde bulunan Dioscoros Theodorus (yaklaşık 1210-1282) isimli Süryanice ders kitabındaki rhipidionun, çağdaş duvar resimlerindeki örneklerle benzerlik gösterdiği belirtilmektedir (Snelders and Immerzeel, 2004, s. 117). İkonoklazma döneminin (726-842/843) tahribatından kaynaklı, erken Bizans dönemine tarihlendirilen rhipidionlardan sadece sınırlı sayıda örnek günümüze ulaşmıştır. Ayrıca bunlardan hiçbiri duvar resmine ait örnekler değildir. Özellikle II. İznik Konsili (787) doğrultusunda sanatçıların bazı göksel düzeni yansıtmaları konusunda bazı kararlar aldıkları belirlenmiştir. 11.-12. yüzyıllarda, ikonoklazmanın etkilerinin tarihe gömüldüğ̈ süreçte, birçok resim programında olduğu gibi rhipidionların da kiliselerdeki duvar resimlerinde yerini aldığ bilinmektedir (Woodfin, 2010, s. 311). 11.-12. yüzyılın mistagojik yazılarında Büyük Giriş’te, kutsal eşyalar ile rhipidionun sunağa götürülmesi ve okunan ilahileri, Andidalı Nikholas'1n metinleriyle desteklemektedir (Schroeder, 2008, s. 42). 


\section{Durmuş GÜR - Cahit KARAKÖK}

12. yüzy1l sonrasına tarihlendirilen kiliselerde, apsis, bema ve kubbe başta olmak üzere naos ve narteks duvarlarında rhipidionlar tasvir edilmiştir. Makedonya Üsküp, Aziz Nerezi Kilisesi'nin (1164) apsisinde, üstteki Havariler Komünyonu'nda, iki ayrı melek ile apsis nişinde altta Hetoimesia'da (Boş That) tasvir edilmiştir. Tahtın iki yanındaki meleklerin ellerinde birer rhipidion bulunmaktadır (Dimitrova, 2015, s. 17). Kıbrıs, Kato Lefkara'da Başmelek Mikhael Kilisesi (12. yüzy1l), Havarilerin Komünyonu'nda kiborion altında iki Başmelek tasvir edilmiştir. Başmeleklerin ellerinde birer rhipidion bulunur. Rhipidionların ortasında dört kanatlı kherublar, kiborionun içindeki boş bölümde duvarda ise Hagios Hagios Hagios yazar (Stylianou and Stylianou, 1997, fig. 266). $\mathrm{Bu}$ durum cherubikon ve rhipidion uyumunun, 12. yüzyıl ve sonrasinda da duvar resimleriyle devam ettiğini göstermektedir. Kiliselerde ilk defa nerede ve hangi yapıda kullanıldığı belirlenemeyen rhipidionlar liturjide hala kullanılmaya devam etmektedir. Sade örneklerin dışında renkli, zengin ve değerli taşlarla süslenmiş kemik, fildişi ve parşömen rhipidionlar, hiçbir zaman tamamen kaybolmamıştır. Floransa Arkeoloji Müzesi'nde bulunan ve Ortaçağ'a tarihlendirilen Tornus Rhipidionu (12. yüzy1l) ile Hohenbourg Rhipidionu (12. yüzy1l) parşömen örneklerdir (Green, 1951, s. 154-155, fig. 5-6). Erken tarihli örneklerin dışında 13.15. yüzy1la tarihlendirilen metinlerden İngiltere, Fransa ve Rusya'da parşömen ve kağıttan yapılmış rhipidionların varlı̆̆ 1 bilinmektedir (Kroos and Wirth, 1991, s. IVA). Katolik kiliselerinde hala kullanılmaya devam eden tavus kuşu tüylü rhipidionlar buna örnektir. Cherubikonların (Kherubik İlahi / $\chi \varepsilon \rho o v \beta 1$ ı̀̀ eşliğinde liturjide kullanılan rhipidionun sembolik hareketleri, zamanla müziğin ritmiyle yeni bir form ve anlam kazanmıştır (Schroeder, 2008, s. 42; Kessler, 2012, s. 22). Çalışma kapsamında incelenen rhipidionlar, Paleologos dönemi (1259-1453) duvar resimlerindeki örnekleri kapsamaktadır. 13.-15. yüzyıl arasına tarihlendirilen Anadolu, Ermenistan, Kıbris, Makedonya, Yugoslavya, Ukrayna, Yunanistan ve Balkanlar'daki birçok kilisede dini ve liturji konulu resimlerde rhipidion yer almaktadır (Stylianou and Stylianou, 1997, fig. 46-47, 169-170, 266; Greenwood, 2015, s. 142-144; Betancourt, 2015, s. 489-510; Kriza, 2017, s. 93, 98-99, fig. 1, 56; Acara-Eser, 2020, s. 77; Gerstel, v.d., 2021, s. 31-49).

Ermenistan Lori'de, Akhtala Manastırı Kilisesi (1205-1216), apsis resim programında, üstteki Havariler Komünyonu'nda, üstünde kiborion bulunan sunağın iki yanında birer İsa yer alır. İsa'nın, arkasındaki melek-diyakonların ellerinde birer rhipidion bulunur. İsa solda Petrus'a artos, sağda ise Pavlus'a kalis sunmaktadır. Melekler ellerindeki rhipidionları, sunak yerine İsa'nın ellerindeki liturjik eşyaların üzerinde sallamaktadır (Lidov, 1998a, s. 347, fig. 5) (Resim 3). 


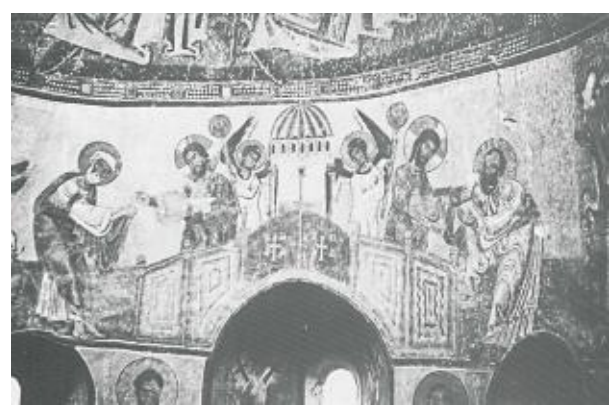

Resim 3. Ermenistan Lori, Akhtala Manastırı Kilisesi (1205-1216), Apsis, Havariler Komünyonu (Lidov, 1998, s. 347, fig. 5)

Mısır, Deir el-Syrian Manastırı (13. yüzyılın ilk yarıs1), apsis yarım kubbesinde, Koimesis Meryem (Meryem'in Ölümü) tasvir edilmiştir. Meryem kline üzerine uzanmış, klinenin arkasında eksende İsa, Meryem'in sembolik ruhunu temsil eden bir bebek tutar. Kilisenin iki ucunda altışardan 12 Havari, İsa'nın iki yanında ise madalyonların ortasında, büst şeklinde iki melek tasvir edilmiştir. Melekler, ellerindeki rhipidionları, İsa'nın üzerine yöneltmektedir. Rhipidionlar, yeşil ve kırmızı taşlarla süslenmiştir ${ }^{7}$ (Resim 4) (Snelders and Immerzeel, 2004, s. 117).

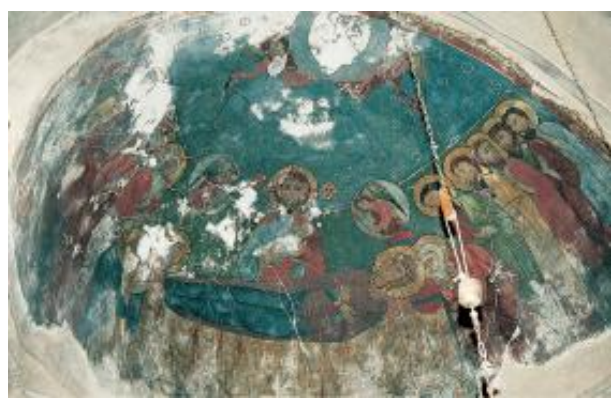

Resim 4. Mısır, Deir el-Syrian Manastırı (13. yüzyılın ilk yarısı), Apsis Yarım Kubbe, Koimesis Meryem (Meryem' in Ölümü)

(Snelders and Immerzeel, 2004, s. 117, Pl. 2)

Makedonya Ohrid, Bakire Peribleptos Kilisesi (1295), apsisindeki Havariler Komünyonu'nda (Betancourt, 2015, s. 494-495, fig. 4), üzerinde kiborion yer alan bir sunak tasvir edilmiştir. Kiborionun bir ayağı, sunağın önünde eksene yerleştirilerek, kompozisyon ikiye bölünmüştür. Sunağın arkasında, iki yanda birer İsa, sol ve sağdaki altışardan 12 Havari'ye komünyon (ekmek ve şarap) sunarken tasvir edilmiştir. Ayinin duygusunu yakalamak için iki defa resmedilen

\footnotetext{
${ }^{7}$ Bunun bir örneğini Süryani El Yazması Synodu'nda (1204) görmek mümkündür (Snelders and Immerzeel, 2004, s. 117).
} 


\section{Durmuş GÜR - Cahit KARAKÖK}

İsa'nın arkalarında, ellerinde rhipidion tutan melek-diyakonlar bulunur. Rhipidionlarda kherub-seraph benzeri tasvirler yer alır. İkili simetrik düzen, liturjinin tamamlayıcısı ve aynı zamanda vurgulayıcısı niteliğindedir (Resim 5).

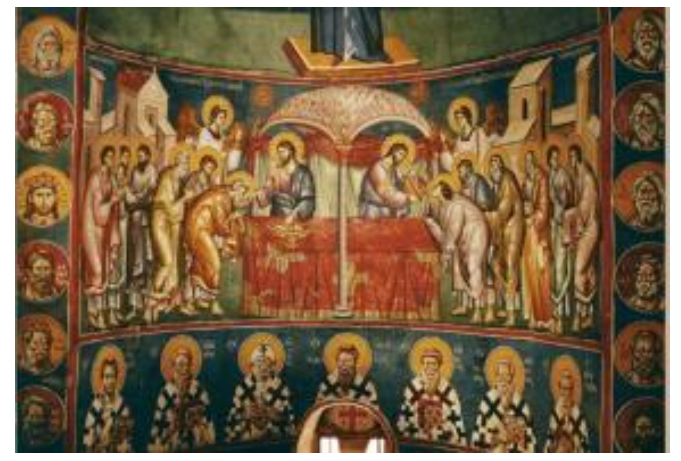

Resim 5. Makedonya Ohrid, Bakire Periblebtos Kilisesi (1295), Apsis, Havariler Komünyonu (Betancourt, 2015, s. 495, fig. 4)

Kapadokya Ihlara Vadisi, Bezirana Kilise (13. yüzyıl), apsis yarım kubbede, sunak çevresinde Ioannes Khrysostomos, Amphilokhios ve Blasios tasvir edilmiştir. Duvar resminde, din adamlarından daha küçük iki melek-diyakon, üzerinde kiborium yer alan sunağın sağ ve solunda tasvir edilmiştir. Melekdiyakonlar, ellerindeki rhipidionları sunak üzerinde sallamaktadır. Rhipidionların üzerinde seraph yer almakta, kiboriumun ortasında, sunăga inmek üzere havada betimlenmiş beyaz güvercin, ruhsal kurtuluşu işaret etmektedir (Resim 6) (JolivetLévy, 2017, s. 116, fig. 12-13).

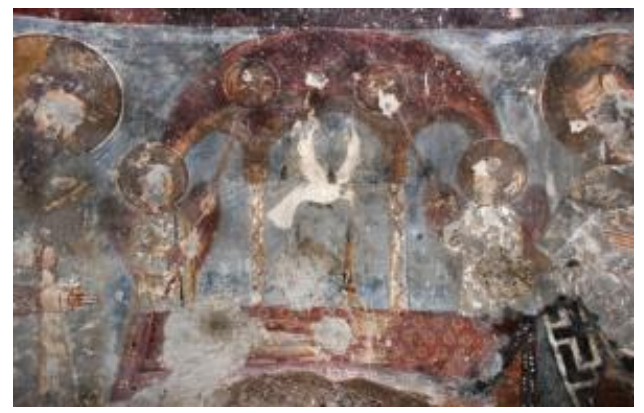

Resim 6. Kapadokya Ihlara Vadisi, Bezirana Kilise (13. yüzy1l), Apsis, Sunak Çevresinde Ioannes Khrysostomos, Amphilokhios ve Blasios (Jolivet-Lévy, 2017, s. 116, fig. 12)

Ohrid, Ayasofya Kilise (14. yüzyılın ilk yarısı), egzonarteksin (dış narteks) üst katında ellerinde rhipidion tutan kutsal melek-diyakonlar yer almaktadır (Kroos and Wirth, 1991, s. IIA1). Resimlerde sunakta, kiborion altında duran İsa, ayin 


\section{Bizans Sanatında Rhipidion (Flabellum) ve Geç Bizans Dönemi...}

kıyafetiyle tasvir edilmiştir. Resimlerde her zaman olmasa da İsa, sunağın iki yanında resmedilmiş, melek-diyakonlar da ellerindeki rhipidionları sunağın üzerine sallarken resmedilmiştir. Bu süreçte İsa, sunaktaki liturjik ürünleri havarilere ikram ederken yüzü sunağa bakmaktadır. Nadir bazı örneklerde İsa, sunağın arkasında durur ve bulunduğu yerden havarilere komünyon (ekmek ve şarap) dağıtır (Kroos and Wirth, 1991, s. IIA1).

14. yüzyılda Havariler Komünyonu resimlerinde sunağın iki yanında resmedilen İsa, soldan gelen havarilere ekmek (artos), sağdan geenlere ise kadehten (kalis) şarap sunmaktadır. İsa'nın arkasında, ellerinde birer rhipidion tutan melekler ise rhipidionları sembolik açıdan sunak üzerinde sallamaktadır.

Makedonya Staro Nagoričane, Aziz George Kilisesi (14. yüzy1l), apsiste Havariler Komünyonu tasvir edilmiştir (Lidov, 1998a, s. 344, fig. 4). Üzerinde kiborion yer alan sunağın arkasında, iki yanda İsa yer alır. İsa, soldaki havariye artos, sağdakine ise kalis (şarap) sunar. İsa'nın yanındaki melekler O'na yardım ederken arkalarındaki melek-diyakonlar ise ellerindeki rhipidionları İsa'nın sunduğu komünyonun üzerinde sallamaktadır (Resim 7).

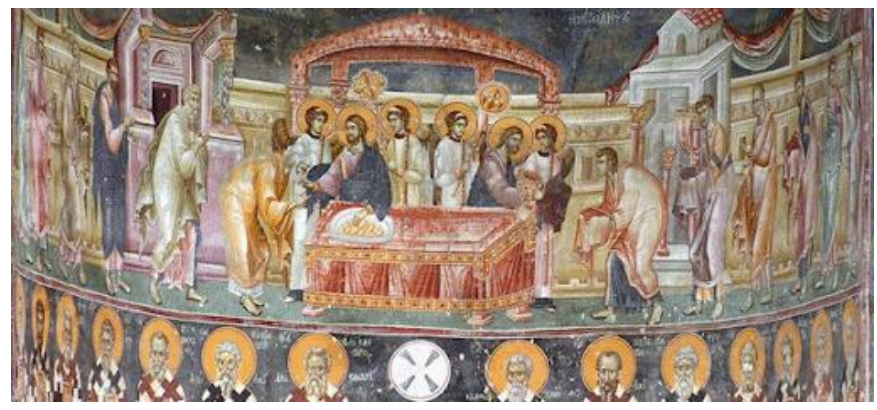

Resim 7. Makedonya Staro Nagoričane, Aziz George Kilisesi (14. Yüzy1l), Apsis, Havariler Komünyonu ${ }^{8}$

Strbistan, Studenica Manastırı, Kral Kilise (1314), apsiste, üstte Havariler Komünyonu tasvir edilmiştir. Kompozisyon, eksendeki pencere nedeniyle ikiye ayrılmıştır. Aynı düzende tasvir edilen kompozisyonun kuzeyindekinde, üzerinde kiborion yer alan sunağın arkasında İsa, elindeki ekmeği havarilere sunarken tasvir edilmiştir. Yanındaki melek, İsa'ya yardım ederken arkasındaki melek-diyakon, üzerinde kherub-seraph bulunan rhipidionu, İsa'nın sunduğu komünyon (ekmek) ile sunak üzerinde sallamaktadır. Eksenin güneyinde, üzerinde kiborion yer alan sunağın arkasında, İsa elindeki şarap dolu kalisi havarilere sunmaktadır. Yanındaki melek, İsa'ya yardım ederken arkasındaki melek-diyakon, üzerinde kherub-seraph bulunan rhipidionu, İsa'nın sunduğu komünyon (şarap) ile sunak üzerinde geometrik süslemeler görülür (Gillette, 2018, s. 38, fig. 7) (Resim 8).

${ }^{8}$ (http, s.//www.stclementofohrid.com/multimedia/frescos.asp 23.10.2021, 19, s. 31) 

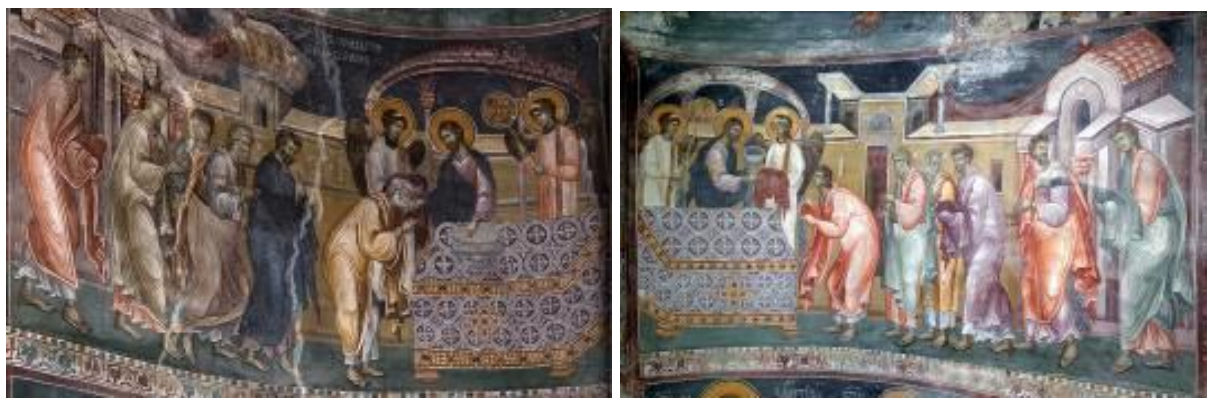

Resim 8. Sırbistan Studenica Manastırı, Kral Kilise (1314), Apsis, Havariler Komünyonu' (Gillette, 2018, s. 38, fig. 7)

Surbistan, Studenica Manastırı, Kral Kilise (1314), Meryem'in Doğumu, kalabalık bir kompozisyon anlayışıyla tasvir edilmiştir. Resmin merkezinde kline üzerinde Anna ve O'na yardım eden iki mabeynci/eşlikçi görülür. Anna'nın arkasındaki mabeynci / eşlikçi ise rhipidionu Anna'nın üzerinde sallamaktadır (Resim 9).

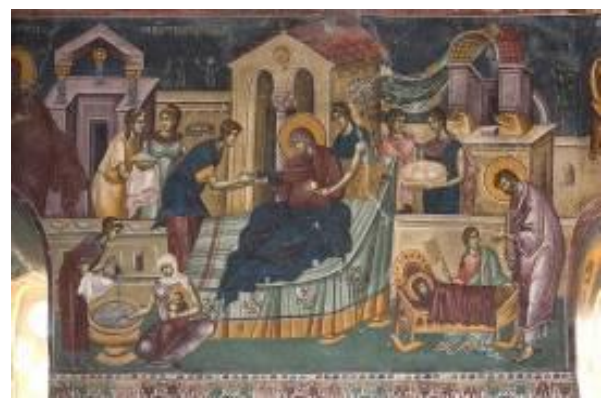

Resim 9. Sırbistan Studenica Manastırı, Kral Kilise (1314), Meryem'in Doğumu ${ }^{10}$

Surbistan, Gračanica Kilise (1321-1322), merkezi kubbede göksel liturji tasvir edilmiştir (Gillette, 2018, s. 33, fig. 3; Betancourt, 2015, s. 497, fig. 5). Kubbede, eksenin solunda ve sağında, sol elleri kapalı, ellerinde kutsal kapaklı liturjik bir kap tutan ve sağ ellerinde buhurdan sallayan meleklerin karşısında, üzerinde seraph tasvir edilmiş rhipidionları tutan melek-diyakonlar tasvir edilmiştir (Resim 10).

\footnotetext{
${ }^{9}$ (https, s.//www.flickriver.com/photos/tags/studenica/interesting/ 22.10.21, 21, s. 18)

${ }^{10}$ (https, s.//www.flickr.com/photos/139456657@N07/46556305085/ 22.10.21, 03, s.18)
} 

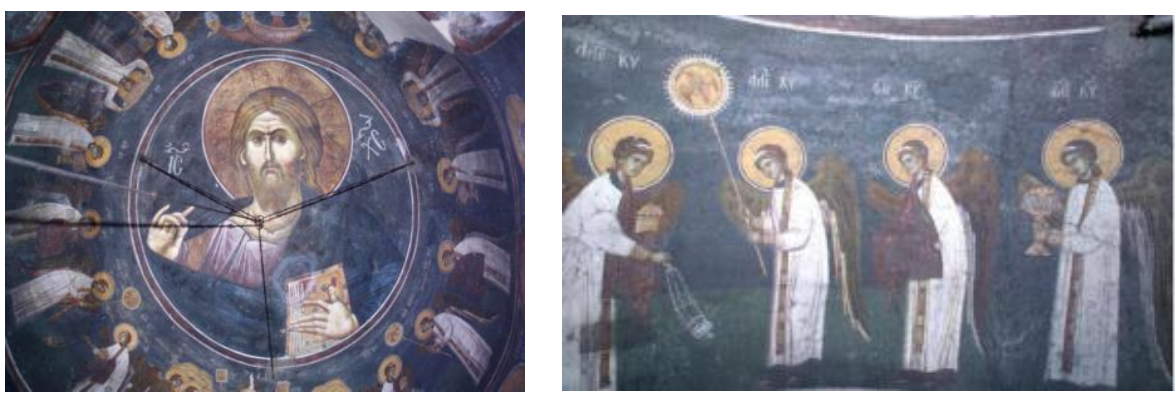

Resim 10. Surbistan, Gračanica Kilise (1321-1322), Merkezi Kubbe, Göksel Liturji (Gillette, 2018, s. 33, fig. 3; Betancourt, 2015, s. 497, fig. 5)

Sırbistan, Gračanica Kilise'de (1321-1322), merkezi kubbe dışında apsiste de rhipidion tasvir edilmiştir. Apsiste üstte eksendeki bir tribelon tarafindan ikiye bölünmüş yüzeyde Havariler Komünyonu tasvir edilmiştir. Sirbistan Studenica Manastır1, Kral Kilise'nin (1314), apsisindeki Havariler Komünyonu (Gillette, 2018, s. 38, fig. 7) tasviriyle benzerlik gösterir. Tribelonun üzerindeki, altı kanatlı seraphlar, ellerinde üzerinde yazıtların bulunduğu rhipidionları tutar. Tribelonun kuzeyinde, üzerinde kiborion yer alan sunağın arkasında İsa, elindeki ekmeği havarilere sunarken arkasındaki melek-diyakon, üzerinde seraph bulunan rhipidionu, sunak üzerinde sallamaktadır. Eksenin güneyinde, üzerinde kiborion yer alan sunağın arkasında İsa, elindeki kalisi (şarap) havarilere sunarken arkasındaki melek-diyakon, üzerinde seraph bulunan rhipidionu, İsa'nın sunduğu komünyon (şarap) ile sunak üzerinde sallamaktadır (Resim 11).

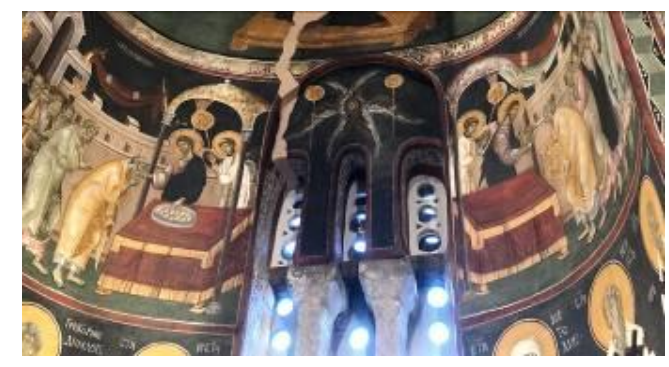

Resim 11. Sırbistan, Gračanica Kilise (1321-1322), Apsis, Havariler Komünyonu ${ }^{11}$

Kariye Camii Parekklesionu'nda (Khora Manastır) (14. yüzyıl) (Akyürek, 1996, s. 15), Meryem'in Doğumu'nu gösteren mozaik panoda, Anna'ya hizmet edenlerin arkasında (mabeynci/eşlikçi) elinde üçgen bir rhipidion tutan kadın, tasvirin kutsallığını vurgulamaktadır. Rhipidionun üzerinde tavus kuşunun tüylerinde görülen gözlerin benzeri bir kompozisyon yer alır. Ayrıca rhipidionu

11 (https, s.//twitter.com/DecaniMonastery/status/1059954022537420801/photo/1 24.10.21, 17, s.27) 


\section{Durmuş GÜR - Cahit KARAKÖK}

tutan kadının üstündeki pandantifte yer alan tavus kuşu tasviri,göksel ve ruhsal kavram arasındaki kutsallığı somutlaştırmaktadır.

Makedonya Lesnova Manastırı'nın (yaklaşık 1342) apsisinde, Başrahip İsa, sunak üzerindeki liturjik eşyaları kutsarken tasvir edilmiştir (Djuric, 2015, s. 129130, fig. 1). Sunağın kuzey köşesinde ekmek, güney köşesinde ise kalis bulunmaktadır. İsa'nın çevresinde mandorla, iki yanında ise ellerindeki rhipidionları sunak üzerinde sallayan seraphlar tasvir edilmiştir. Kuzeydeki seraphın elindeki rhipidion dairesel, güneydekinin elindeki ise sekizgendir. Rhipidionların yüzeylerinde, seraph (?) tasvir edilmiştir (Resim 12).

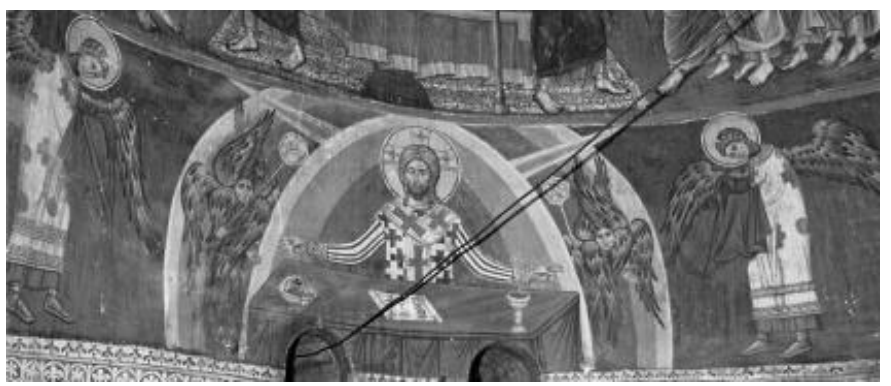

Resim 12. Makedonya Lesnova Manastırı (yaklaşık 1342), Apsis, Başrahip İsa'nın Liturjik Eşyaları Kutsaması (Djuric, 2015, s. 130, fig. 1)

Makedonya, Pološko Aziz Georges Kilisesi’nde (1343-1345), Havariler Komünyonu tasvir edilmiştir (Popova, 2015, s. 161-163, fig. 1-2). Havariler Komünyonu, iki parçalı olarak düzenlenmiş, naosun kuzey ve güney duvarlara yerleştirilmiştir. Kuzeyde, kiborion altındaki sunağın arkasında, sakkos giyimli İsa'nın boynunda omophorion, başında ise hale yer alır. İsa, sol eli kutsal ekmek kabında (artophorion-?), sağ eliyde de kutsal ekmeği (artos) öndeki Petrus ve arkasındaki havarilere sunarken tasvir edilmiştir. İsa'nın arkasındaki melekdiyakon, üzerinde dört kanatlı kherub bulunan dairesel rhipidionu İsa'nın arkasından uzanarak İsa ve komünyon üzerinde salladığı görülür. Komünyon sahnesinin devamı niteliğinde tasvir edilen güney duvarda ise, İsa elindeki büyük kalisten havarilere şarap sunarken tasvir edilmiştir. Burada İsa'nın arkasındaki meleğin elinde rhipidion bulunmamaktadır. Kuzey ve güney duvarda, komünyonda tasvir edilen sunak ile İsa'nın omophorion renkleri farklıdır (Resim 13). 


\section{Bizans Sanatında Rhipidion (Flabellum) ve Geç Bizans Dönemi...}
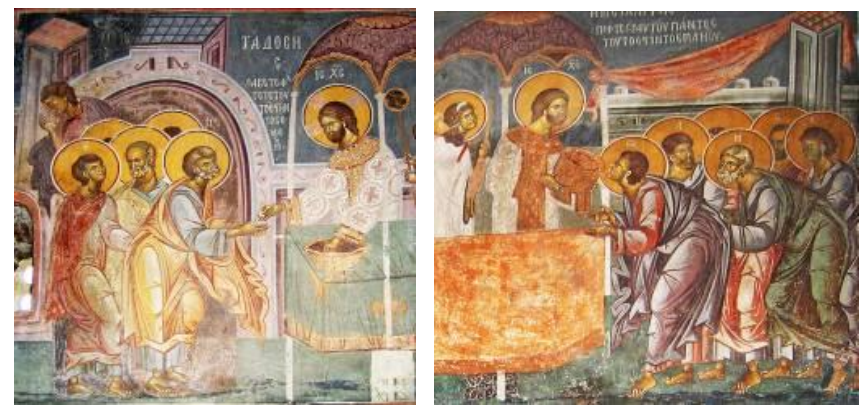

Resim 13 a-b. Makedonya, Pološko Aziz Georges Kilisesi (1343-1345), Havariler Komünyonu (Popova, 2015, s. 162, fig. 1)

Makedonya Üsküp, Markov Manastırı (1375), apsis ve bemada, büyük giriş tasvir edilmiştir. Kuzey ve güney bema duvarında ikişerden dört, apsiste eksende, üzerinde kiborion yer alan sunağın arkasındaki İsa'nın iki yanında, din adamlarının arkasından ellerindeki ikişer rhipidionu sunağa sallayan melekdiyakonlar bulunmaktadır ${ }^{12}$ (Resim 14-15) (Betancourt, 2015, s. 509, fig. 11).

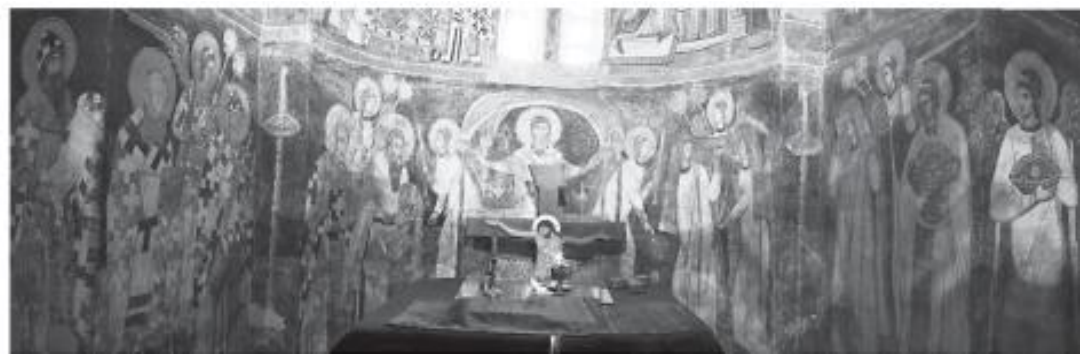

Resim 14. Makedonya Üsküp, Markov Manastırı (1375), Apsis, Büyük Giriş (Betancourt, 2015, s. 510, fig. 11; Djuric, 2014, s. 131, fig. 8)

12 Makedonya Üsküp, Markov Manastırı'nda (1375), olduğu gibi çok yoğun rhipidionun tasvir edildiği kiliseleri Yunanistan ve Balkanlar'daki kiliselerin duvar resimlerinde görmek mümkündür (Resim 13-14) (Djuric, 2014, s. 131, Fig. 8; Betancourt, 2015, s. 497, fig. 5; Gillette, 2018, s. 33, Fig. $3)$. 

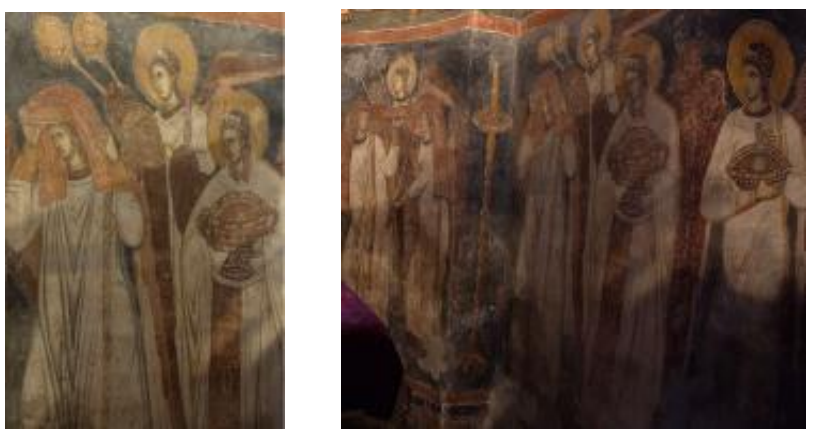

Resim 15a-b. Makedonya Üsküp, Markov Manastırı (1375), Apsis ve Bema, Büyük Giriş (Betancourt, 2015, s. 510, fig. 11-4, 11-5)

Romanya, Curtea de Argeş Manastırı (Yaklaşı1 1376-1377), prothesiste kiborion altında ölmüş İsa'nın baş ve ayak ucunda ellerindeki rhipidionları İsa'nın üzerinde sallarken tasvir edilmiş melekler bulunur. Başları ile ellerindeki rhipidionları, kiboriona yönelten melekler, olayın gerçekleştiği kompozisyonun dini gücünü yansitmaktadır (Resim 16) (Djuric, 2014, s. 130, fig. 7).

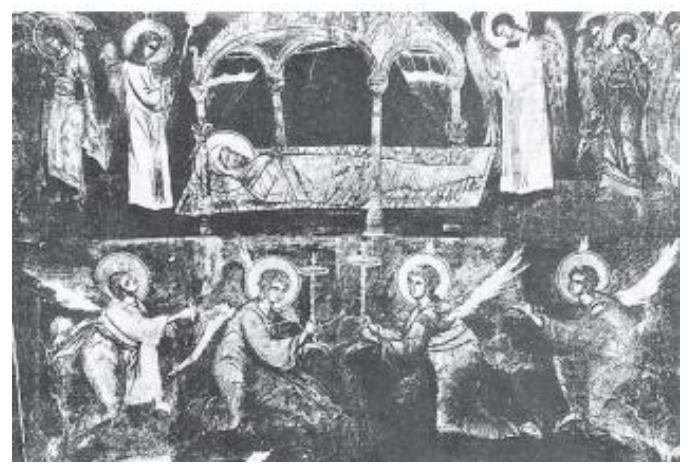

Resim 16. Romanya, Curtea de Argeş Manastırı (Yaklaşık 1376-1377), Prothesis, İsa'nın Ölü Bedeni Başında Melekler (Djuric, 2014, s. 130, fig. 7)

Yunanistan Valsamonero Manastırı'nın narteksinde yer alan Aziz Phanourios Şapeli'nin (1430-1431), apsisinde büyük giriş tasvir edilmiştir (Djuric, 2014, s. 136, fig. 16, Drandaki, 2017, s. 390-391, fig. 16). Üstte Pantokrator İsa, altta ise büyük giriş tasvir edilmiştir. Liturjinin sunulduğu tasvirinde sağda kiborion planlı sunağının önünde İsa, büyük başrahip şeklinde, mücevherli sakkos giyimli olarak tasvir edilmiştir. Sol elinde kapalı kutsal kitap tutarken sağ eliyle takdis işareti yapan İsa'nın karşısında, ellerinde liturjiyle ilgili kutsal kapları taşıyan melekler, kutsanmak için İsa'ya yönelmiştir. Öndeki meleklerin arkasında, elinde iki rhipidion tutan melek-diyakon bulunmaktadır. Buradaki tüm figürlerin başı haleli, elinde rhipidion tutan melek-diyakonun başındaki hale ise diğerlerinden 


\section{Bizans Sanatında Rhipidion (Flabellum) ve Geç Bizans Dönemi...}

farklı renkte sunulmuştur. Bu durum O'nun görevi ve liturjideki rhipidionun önemini belirtmek için yapılmıştır (Resim 17).

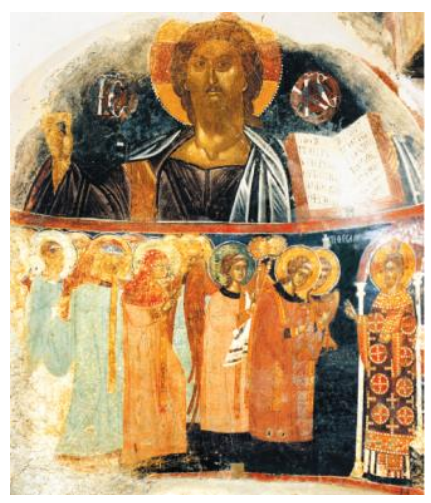

Resim 17. Yunanistan Valsamonero Manastırı, Aziz Phanourios Şapeli (1430-1431), Apsis, Büyük Giriş (Drandaki, 2017, s. 390-391, fig. 16)

\section{Üslup ve İkonografi}

Çalı̧̧ma kapsamında incelenen örneklerin hepsi duvar resimidir. Kiliselerde, apsis, bema, kubbe, naos ve narteks duvarlarında tasvir edilen Havariler Komünyonu, İsa'nın Liturjik Eşyaları Kutsaması, İsa'nın Ölü Bedeni Başında Bekleyen Melekler, Koimesis Meryem (Meryem'in Ölümü), Büyük Giriş ve Küçük Giriş'e ait kompozisyonlarda; melekler, melek-diyakonlar ya da seraphların ellerinde rhipidionlar tespit edilmiştir.

İncelenen rhipidionların üzerinde çoğunlukla değerli taşlar, geometrik kompozisyonlar ya da kherub ve seraph tasvirleri yer almaktadır. Kherub ve seraph tasvirleri çoğunlukla birbirine karıştırılmaktadır. Seraphlar, altı kanatlıdır, ellerinde kherublardan farklı olarak kılıç ya da mızrak tutar. Kherubların Bizans resim sanatında dört yerine altı kanatlı olarak tasvir edilmesi, karışıklığı önlemeye yönelik düzenlenmiş bir kural şeklinde yorumlanmaktadır (Mango, 1962, s. 86, Doğan ve Ünser, 2011, s. 205). Özellikle kiliselerdeki rutsal mekanlarda duvar resimlerinde tasvir edilen seraph ve kherubların, göksel varlıkların koruyucu yapısına sembolik açıdan gönderme yapmak için rhipidionlarda tasvir edildiği bilinmektedir. Ayrica bu durum, duvar resimlerindeki rhipidionları ellerinde tutan ya da sallayan melekler ile melek-diyakonları açıklamaktadır.

Melek-diyakonlar tarafından taşınan rhipidionlar çoğunlukla dairesel formda, uzun birer sap yardımıyla sunağın üzerin ya da kutsal olayın gerçekleştiği yöne sallanmakta/uzatılmaktadır (Acara-Eser, 2020, s. 77). Makedonya Üsküp Aziz Nerezi Kilisesi (1164), Havariler Komünyonu ve Hetoimesia'da (Boş That) (Dimitrova, 2015, s. 17), Ermenistan Lori, Akhtala Manastırı Kilisesi (1205-1216), Havariler Komünyonu'nda (Lidov, 1998a, s. 347, fig. 5), Misır Deir el-Syrian Manastırı (13. yüzyılın ilk yarıs1), apsis yarım kubbesi, Meryem'in Ölümü'nde (Koimesis Meryem) (Snelders and Immerzeel, 2004, s. 117, Pl. 2), Makedonya 


\section{Durmuş GÜR - Cahit KARAKÖK}

Ohrid, Bakire Periblebtos Kilisesi (1295), apsisteki Havariler Komünyonu'nda (Betancourt, 2015, s. 495, fig. 4), Makedonya Staro Nagoričane, Aziz George Kilisesi (14. yüzyıl), apsisteki Havariler Komünyonu'nda, Sirbistan Studenica Manastır1, Kral Kilise (1314), apsisteki Havariler Komünyonu'nda (Gillette, 2018, s. 38, fig. 7), Surbistan Studenica Manastır1, Kral Kilise (1314), Meryem'in Doğumu'nda, Sirbistan Gračanica Kilise (1321-1322), merkezi kubbedeki göksel liturji ile apsisteki Havariler Komünyonu'nda (Gillette, 2018, s. 33, fig. 3, Betancourt, 2015, s. 497, fig. 5), Makedonya Lesnova Manastırı (yaklaşık 1342), apsisteki Başrahip İsa tasvirinde (Djuric, 2015, s. 129-130, fig. 1), Makedonya, Pološko Aziz Georges Kilisesi (1343-1345), Havariler Komünyonu, kuzey duvarda (Popova, 2015, s. 162, fig. 1), Makedonya Üsküp, Markov Manastırı (1375), apsis ve bemadaki Büyük Giriş’te (Betancourt, 2015, s. 510, fig. 11; Djuric, 2014, s. 131, fig. 8), Romanya, Curtea de Argeş Manastırı (yaklaşık 1376-1377), prothesiste, İsa'nın Ölü Bedeni Başında Melekler (Djuric, 2014, s. 130, fig. 7), Peloponnese, Velanidia, Aziz Panteleimon Kilisesi (geç 13. yüzyıl), İsa'nın ölü bedeni başında melekler (Gkioles and Pallis, 2014, s. 228) ve Yunanistan Valsamonero Manastırı'nın narteksinde yer alan Aziz Phanourios Şapeli'nin (1430-1431), apsisindeki Büyük Giriş’te (Djuric, 2014, s. 136, fig. 16; Drandaki, 2017, s. 390391, fig. 16) dairesel formda rhipidionlar tasvir edilmiştir. Riha ve Stuma hazinelerindeki (565-578) rhipidionların disk formu ve dilimli kenar bordürleri, 11. yüzyıl sonrasına tarihlendirilen kilise duvar resimlerindeki rhipidionlarda üslup ve form açısından yansitılmaya devam etmiştir (Kroos and Wirth, 1991, Abb. 1a-b; Doğan ve Ünser, 2011, s. 2015, Res. 3-4). Ayrıca çalışmanın konusunu oluşturan 13.-15. yüzyıl Kıbrıs, Makedonya, Yunanistan ve Balkanlardaki bazı kiliselerde, dört kenarı yarım daire genişletilmiş örneklerin dışında sadece disk formunda ve melek tasvirli (kherub ve seraph) rhipidionlar bulunmaktadır (Stylianou and Stylianou, 1997, fig. 46-47 169-170, 266; Greenwood, 2015, s. 142-144; Betancourt, 2015, s. 489-510; Popova, 2015, s. 161-163, fig. 1-2; Acara-Eser, 2020, s. 77; Acara-Eser, 2020, s. 77; Gerstel, v.d., 2021, s. 31-49).

Üzerlerinde kherub-seraphların tasvir edildiği rhipidionlar, liturjinin ve kompozisyonun önemini göstermektedir. Makedonya Üsküp, Markov Manastırı (1375), apsiste Büyük Giriş (Betancourt, 2015, s. 510, fig. 11; Djuric, 2014, s. 131, fig. 8), Romanya Curtea de Argeş Manastırı (yaklaşık 1376-1377), Prothesis (Djuric, 2014, s. 130, fig. 7) ve Yunanistan Valsamonero Manastır1, Aziz Phanourios Şapeli (1430-1431), apsisteki Büyük Giriş (Drandaki, 2017, s. 390-391, fig. 16) tasvirlerinde, melek-diyakonların ellerinde ikili rhipidionlar yer almaktadır. Aynı düzen Markov Manastırı'nda (1375), liturjinin devamı niteliğinde olan kuzey ve güney bemada da görülmektedir (Betancourt, 2015, s. 510, fig. 11, Djuric, 2014, s. 131, fig. 8). Burada melek-diyakonların iki elinde tuttukları rhipidionlar, uzaktan bakıldığında alttan birleşik gibi görünse de her elinde bir tane rhipidion tuttuğu daha yakında bakıldığında fark edilmektedir. Ayrıca Üsküp Markov Manastırı (1375) ve Yunanistan Valsamonero Aziz Phanourios Manastırı (1431), apsisteki Büyük Giriş’teki (Djuric, 2014, s. 136, fig. 16) ikili rhipidionlara benzer bir düzenleme görülmektedir. 14. yüzyıla tarihlendirilen kitap kapakları ve duvar 


\section{Bizans Sanatında Rhipidion (Flabellum) ve Geç Bizans Dönemi...}

resimlerinde de ikili rhipidionların tasvir edildiği bilinmektedir. Örneğin İngiliz krallarının taç giydiği bilinen Londra'daki Westminster Abbey Kilisesi'nde 14. yüzyıla tarihlendiriln gümüş bir rhipidionun dışında, iki disk şeklindeki rhipidion tasvirli kutsal kitabın da 14. yüzyıla tarihlendirildiği bilinmektedir (Von Fürstenberg, 1979, s. 170). İkili rhipidionların bu dönemde daha çok göksel liturji ve törensel faaliyetlerle ilişkili dini yapılarda kullanıldığı düşünülmektedir.

Melek-diyakonlar tarafindan taşınan rhipidionlardan bazıları dışında diğerleri doğrudan ikonografik sayneye yönlenmiştir. Özellikle Havariler Komünyonu tasvirlerinde, bazı melek-diyakonların, rhipidionları sunak üzerindeki liturjik eşyalar yerine İsa'nın elindeki şarap ve ekmeği işaret edecek şekilde, İsa'nın arkasından O'na doğru salladığı görülmektedir. 13.-14. yüzyıla tarihlendirilen birçok kilisede bu anlatı̧̧ doğrultusunda oluşturulmuş birçok tasvir bulunmaktadır. Ermenistan Lori, Akhtala Manastırı Kilisesi (1205-1216), apsisteki Havariler Komünyonu (Lidov, 1998a, s. 347, fig. 5), Makedonya Staro Nagoričane, Aziz George Kilisesi (14. yüzy1l), apsisteki Havariler Komünyonu, Sirbistan Studenica Manastır1, Kral Kilise (1314), apsisteki Havariler Komünyonu (Gillette, 2018, s. 38, fig. 7) ve Makedonya, Pološko Aziz Georges Kilisesi (1343-1345), Havariler Komünyonu, kuzey duvardaki (Popova, 2015, s. 162, fig. 1) tasvirler buna örnektir. Bu durum 13. ve 14. yüzylla ait iki ayrı metinde, rahiplerin rahatsız olmaması için rhipidionların kullanıldığının belirtilmesi, liturjik eserler kadar din adamlarının da toz ve böceklerden rhipidionlar yardımıyla uzaklaştırıldığını desteklemektedir (Kroos and Wirth, 1991, s. IIA1). Misır, Deir el-Syrian Manastır1 (13. yüzyılın ilk yarıs1), apsis yarım kubbesindeki, Koimesis Meryem (Meryem'in Ölümü) (Snelders and Immerzeel, 2004, s. 117, Pl. 2) tasvirinde, melekler, ellerindeki rhipidionları, kline üzerinde uzanan Meryem yerine, İsa'nın elinde tuttuğu Meryem'in kutsal ruhu üzerinde salladığı görülmektedir. Bu durum, teoloik bakışın Meryem yerine İsa ve Meryem' in ruhuna yöneltilmesi hususuyla açıklanabilir.

Melek / melek-diyakonlarn ellerindeki rhipidionlar, sunak, kiborion ya da kutsal kişilerin üzerinde sallanırken tasvir edilmiştir. Makedonya Ohrid, Bakire Periblebtos Kilisesi (1295), apsisteki Havariler Komünyonu'nda (Betancourt, 2015, s. 495, fig. 4), kiborionun üzerine, Kapadokya Ihlara Vadisi Bezirana Kilise (13. yüzy1l), apsiste sunak çevresindeki Ioannes Khrysostomos, Amphilokhios ve Blasios (Jolivet-Lévy, 2017, s. 116, fig. 12) tasvirinde, kiborionun önünde ve sunak üzerine, Makedonya Staro Nagoričane, Aziz George Kilisesi (14. yüzyıl), apsisteki Havariler Komünyonu'nda, kiborionun altında ve sunak üzerine, Romanya, Curtea de Argeş Manastırı (Yaklaşık 1376-1377), prothesisteki İsa'nın Ölü Bedeni Başında Melekler'in (Djuric, 2014, s. 130, fig. 7), ellerindeki rhipidionlar kiborion üzerinde sallanırken gösterilmiştir.

Tasvir edilen rhipidionlar çoğunlukla sarı ve sarı tonlarındadır. Özellikle dini figürlerin başlarındaki haleler ile benzer tonlara sahip olan rhipidionlar, sarı renkleri ve dini yapılardaki ortak kullanımları kapsamında ele alındığında, sahnenin ikonografik gücüyle renk kurgusunun bağlantılı olduğunu gösterir. Ayrıca Sırbistan Kara, Beyaz Kilise'de (14. yüzyıl) apsiste, sunağın arkasında, din 


\section{Durmuş GÜR - Cahit KARAKÖK}

adamları üzerine rhipidion sallayan üç melek-diyakon görülmektedir. Eksenin güneyindeki ile kuzeyindeki meleklerden öndekinin elindeki rhipidion disk, arkadakinin ise eşkenar dörtgendir. Sarı tonlara sahip rhipidionların kenarlarındaki beyaz inci süslemeler, din adamlarının başlarındaki sarı halelerde de görülmektedir. $\mathrm{Bu}$ durum rhipidion-hale ile renk-kutsallık ilişkisinin yansitmaktadir.

Makedonya Lesnova Manastırı (yaklaşık 1342), apsisteki Başrahip İsa'nın kutsal eşyaları kutsamasında (Djuric, 2015, s. 130, fig. 1), İsa'nın iki yanındaki seraphlar ile Surbistan, Gračanica Kilise (1321-1322), apsiste Havariler Komünyonu kompozisyonunu ikiye bölen tribelonun üzerindeki seraphın ellerinde rhipidion görülür. Makedonya Lesnova Manastırı (yaklaşık 1342), örneğinde seraphların elinde bir rhipidion yer alırken Surbistan, Gračanica Kilise'deki (13211322) seraphın iki elinde birer rhipidion bulunur. İncelenen örneklerden Markov Manastırı'nda büyük girişteki, melek-diyakonların ellerindeki rhipidionların

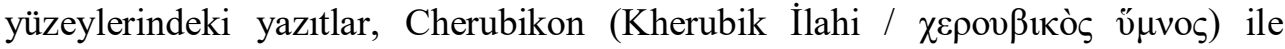
bağlantılıdır. Makedonya, Treskavec Manastırı (1340), kubbede yer alan ökaristi tasvirinde, İsa tıpkı bir kral gibi tasvir edilmiştir. Yazıtta İsa'dan Kralların Kralı olarak bahsedilmektedir. Kral Davud ve Kraliçenin arkasında kherub ve seraph yer almaktadır. Üzerinde Kutsal, Kutsal, Kutsal yazılı rhipidion tutan göksel varlık (seraph), rhipidionların üzerlerindeki yazıtların liturjideki Cherubikon ile bağlantısını göstermektedir (Popova, 2015, s. 165). Ayrıca burada "Heavenly Court" olarak ilk örneğin olduğu belirtilen kompozisyonda yoğun melekler ve arasındaki kherub ve serap tasvirleri, liturjideki meleklerin önemini ve üzerindeki yazıtlı rhipidionun 14. yüzyıldaki gücünü göstermektedir (Popova, 2015, s. 165; Vasileski, 2016, s. 21). İncelenen duvar resimlerinden Misir, Deir el-Syrian Manastırı (13. yüzyılın ilk yarısı), apsis yarım kubbesindeki rhipidionlar, yeşil ve kırmızı değerli taşlarla bezenmesiyle diğerlerinden farklıdır (Snelders and Immerzeel, 2004, s. 117, Pl. 2).

Mısır, Deir el-Syrian Manastırı (13. yüzyılın ilk yarıs1), apsis yarım kubbesindeki Koimesis Meryem (Meryem'in Ölümü) (Snelders and Immerzeel, 2004, s. 117, Pl. 2) tasvirinde, İsa'nın iki yanında, ellerinde rhipidion tutan meleklerin, 13.-15. yüzyıl örneklerinde alışılmış bir üslup anlayışından farklı sunulduğu görülmektedir. Madalyonlar içinde büst şeklinde tasvir edilen meleklerin sadece ellerindeki değerli taşlarla süslü rhipidionların madalyon dışına taştığı görülmektedir.

\section{Değerlendirme ve Sonuç}

Liturjik eserler, kiliselerde cenneteki tanrısal seramoninin yeryüzünde yansıtılması açısından büyük öneme sahiptir. Göksel ve dini makamların analojisi, patristik dönemin başlangıcından itibaren çeşitli şekillerde yansıtılmıştır. Göksel hiyerarşinin aynası olarak liturjilerde birçok nesne kullanılmaya başlanmıştır. İmparator VII. Konstantin'in (913-959) saray mensuplarına uyguladığı hiyerarşik düzenin, ikinci yüzyılda Antakyalı Ignatius tarafından metinlerinde anlatıldığı bilinmektedir. Dini hiyarerşide İsa ve havarilerin konumuyla kiliselerde rahiplerin 


\section{Bizans Sanatında Rhipidion (Flabellum) ve Geç Bizans Dönemi...}

meclisindeki piskopos düzeni eşdeğer olarak kabul edilir. Pseudo-Dionysios'un, The Celestial Hierarchies / The Ecclesiastical Hierarchies adlı (eşleştirilmiş) çalışmalarında, dünyevi düzenin göksel bir düzenle eşleştirilerek yansıtıldığı belirtilmektedir. İfadelerin görsel sanatlar üzerindeki etkisine dair erken Bizans dönemine ait birkaç örnek bu durumu deteklemektedir. Teolojik yansımayı, Kuzey Suriye'de Kaper Koraon Hazinesi'ndeki liturjik eserlerde (6.-7. yüzyıl) görmek mümkündür. Liturjik eserlerden birinin üzerinde, kiborion altındaki sunakta İsa ayakta dururken ellerinde liturjik kaplar yer almaktadır. Bu gibi uygulamalar İsa'nın liturjiye başkanlık ettiği şeklinde yorumlanır. Göksel gerçekliğin dünyevi ayinlere müdahalesi, liturjik eserler üzerinde yansitılırken öğelere rhipidionların da dahil olduğu görülmektedir (Woodfin, 2010, s. 310).

Malzeme ve teknik özellikleri açısından değerlendirildiğinde, erken Bizans döneminde ve hala Katolikler tarafindan rhipidionlarda sıkça tavus kuşu tüyünün tercih edilmesinin özel bir nedeni bulunmaktadır (Von Fürstenberg, 1979, s. 157165). Tavus kuşu tüyünden yapılan rhipidionların özel bir hareket çağrışımı bulunmaktadır. Özellikle liturji sırasında, diyakonun rhipidionu rahibin arkasından geçirirken, tüylerindeki hareketlilik ile tavus kuşu tüyleri üzerinde çok fazla göz şeklinde desen bulunması, rhipidionların görsel ve işitsel şölen sunduğu şeklinde açılanmaktadır (Kessler, 2012, s. 17; Greenwood, 2015, s. 142). Ayrica rhipidionların tasarımlarından kaynaklı, hareket ettirildiğinde yumuşak bir ses ve 1şık efekleriyle liturjiye katılanları etkilediğine inanılır ${ }^{13}$ (Šakota, 2004, s. 134).

Büyük Giriş’te Cherubikon okunurken gerçekleştirilen seramoni, Cennetteki ev sahiplerinin tezahürü olarak yorumlanır. Liturjide kullanılan rhipidionların yüzeyinde genellikle kherub, seraph veya tetramorph bulunmaktadır. Andidalı Nikholas/Theodore'nin yazılarında "rhipidialar... bir tür Kerubim gibidir" ifadesi geçer (Betancourt, 2015, s. 519). Bu durum liturji sırasında hareket ettirilen rhipidionların, yüzeylerindeki meleklerin temsili melek kanatları şeklinde çırpınan bir etki uyandırdığı, bu kanatların da aynı şekilde dua edenleri altında (kanatların altında) barındırarak kötülüklerden koruduğuna inanılmaktadır (Betancourt, 2015, s. 519). Bu uygulamaları, 6. yüzyıldan itibaren tasvir edilen örneklerin üzerindeki seraph ve kherub tasvirlerinden de takip etmek mümkündür. Özellikle liturjik eserlerde sukça tercih edildiği (Ballian, 2004, s. 133; Djuric, 2014, s. fig. 11; Woodfin, 2015, s. 25, fig. 8; Gillette, 2018, s. 34, Resim 4), bilinen ilk ve erken örnekleri olan Riha ve Stuma hazinelerindeki tasvirleriyle desteklenmektedir (Kroos and Wirth, 1991, Abb. 1a-b; Doğan ve Ünser, 2011, s. 2015, Res. 3-4). Sunağa ulaşan melek-diyakon, rhipidionu bir taraftan diğer yana salladığında güçlenen yanar-döner tavus kuşu tüyleri, şöleni hareketlendirmekte, bu etki sonradan çeşitli malzemelerle yapılan rhipidionlarla da sürdürülmektedir. Sembolik açıdan melek olarak kabul edilen diyakonlar böylece sunakta beden ve kan arasında fenomenolojik bir ilişki kurmakta, liturjinin cennette gerçekleştiği etkisini yansitmaktadır. Sunakta tahtta oturduğu bilinen İsa'nın yanında yer alan melekler ile ilişkilendirilen rhipidion ve onları taşıyan diyakonların üzerlerindeki

\footnotetext{
${ }^{13}$ Liturji - ses ilişkisi, ve dini ortamlardaki melek sesleri ile mistik teolojinin yansımaları için bakınız; (Gerstel, v.d., 2021, s. 31-49).
} 


\section{Durmuş GÜR - Cahit KARAKÖK}

melek giyisileri, olayın cennetteki melekler tarafindan onurlandırılması şeklinde yorumlanmaktadır (Kessler, 2012, s. 17).

Ortodoks Hıristiyan dünyasında rhipidionlardaki ikonografik tasvirlerin sembolik unsurlardan oluştuğu bilinir. Araştırmalar göstermiş̧ir ki, Kapadokya'da (Kappadokia) Bizans ordusunu kuran ya da yeniden atanan askeri subayların kiliselerde köklü bir geleneği vardır. Bu da askeri ve zengin kişilerin bağışlarını anlatan yazıtlarda ifade edilmiş ve Başmelek Gabriel ile Mikhael, göksel orduların komutanı olarak kabul edilmiştir (Jolivet-Lévy, 2012, s. 141-161; Greenwood, 2015, s. 143). Areopaguslu Dionysios (6. yüzy1l), melekleri üçlü grup halinde, hiyerarşik düzenlerine göre gruplandırmıştır. Dionysos; Kherub, Seraph ve Tahtlar'1, Tanrı'ya en yakın melekler grubunda değerlendirmiştir (Doğan ve Ünser, 2011, s. 199-200). Duvar resimlerindeki rhipidilar, çok küçük boyutta ya da apsislerde yerden çok yukarıda resmedildiği için ortalarında kherub ya da seraph $\mathrm{m} 1$ bulunduğu net olarak belirlenememiştir. Günümüze ulaşan küçük buluntular, rhipidionların üzerindeki kherub ve seraphlar hakkında bilgiler sunar. Kherubların kanatlarından yukarıdaki ikisi, birbirinin üzerine gelecek şekilde düzenlenmiş, üzerinde ise çok sayıda göz bulunmaktadır. Dört ya da altı kanatlı göksel varlıkların kanatlarının ortasında, tek başına insan yüzü yer aldığ gibi insaneyüzü çevresinde çoğunlukla İncil yazarlarının sembolü olan dört apokaliptik yaratığın (Luka/öküz, Markus/aslan, Matta/insane ve Yuhanna/kartal) başı tasvir edilmiştir. Kherub'un altaki iki kanadıyla kapatılmış insan ayakları yer alır. İki kanadıyla uçtukları bilinen kherubların iki eli yanlardan görülmekte, bazen elleri açık ve boş bazen de mızrak ya da kılıç taşımaktadır. Altta ya da alt iki yanda ateşten tekerlekler (Ezekiel, 1, s. 15-21) kherublara eşlik etmekte ya da yakınında bulunmaktadır (Doğan ve Ünser, 2011, s. 204).

Kaper Koraon Hazinesi'ndeki rhipidion (577), erken tarihli bir örnektir (Woodfin, 2010, s. 310). Rhipidionun ön yüzünde riha ve stuma hayranları tarafından Ezekiel'in taht-araba vizyonundan türetildiği görülen tekerlekli, kıvrık dört kanatlı, dört yüzlü (insan, aslan, sığır/boğa, melek) kherub yer alır (Woodfin, 2010, s. 310). Bu düzen küçük el sanatlarında sıkça işlenmişken duvar resimlerinde uygulanmamıştır. Rhipidionların üzerinde yer alan melek tasvirleri sembolik bir kullanımı gösterir. Diyakonlar, rhipidionları sunak çevresinde taşıma ve sallamanın yanında göksel meleklerin görevini de devralmıştır (Woodfin, 2010, s. 310). Liturjideki dünyevi ve göksel varlıkların arasındaki bağlantı, patristik kaynaklarla sağlanmıştır. Diyakonların, ayin sırasında naostaki insanlar ile kutsal alandaki rahipler arasında araci/haberci (angeloi) olarak hareket ettikleri bilinir. Çeşitli metinlerde melek kanatlarıyla tasvir edilen diyakonların, hatta rhipidionlar üzerinde betimlenen melek tasvirlerini, Tanrı'nın tahtı çevresinde sallayarak, dünyevi-teoloik bir bağ sundukları bilinir. Diyakonlar tarafindan sallanan yelpazelerin, zengin ve değerli taşlarla süslenmesi de dini ve dünyevi kurgu arasındaki gücü yansıtmak amacıyla uygulanmış bir yöntemdir (Woodfin, 2010, s. 311). Rhipidionların kutsal meleklerle ilişkisi erken Bizans dönemi ve öncesine

dayanmaktadır. 4. yüzyıla tarihlendirilen kutsal metinler, Kaper Koraon Hazinesi'ndeki rhipidion (577), Mikhael III'ün mektubunda (858-867 aras1), Codex 


\section{Bizans Sanatında Rhipidion (Flabellum) ve Geç Bizans Dönemi...}

Vigilanus'ta (976), Aziz Lambert'in yaşamını gösteren minyatür (12. yüzyı1), Deir al-Surian'daki bronz rhipidion (1202-1203) üzerindeki yazıt, rhipidionların üzerinde tasvir edilen melekleri açıklamaktadır (Kessler, 2012, s. 16). Dünyevi ve semavi gerçeklik arasında özgürce çağrışımlar kuran liturjik eserlerdeki tasvirlerin, II. İznik Konsili'nde (787) alınan kararlar doğrultusunda yeni bir sürece sahip olduğu, bu dönem sonrasında alınan kararlar sonucunda sanatçıların bazı göksel düzeni tasvirlerde sıkça yansıttıkları bilinir. İkonoklazma dönemindeki (726842/843) etkiler, erken Bizans döneminden itibaren bu tür sanat eserlerinin çoğunun tahrip olmasına neden olmuştur. İkonoklazma sonrasında bu ikonografinin daha da gelişmesi, ironik bir şekilde, ikona hürmetinin ortodoksluğunu sürdürmek için kullanılan argümanlar tarafindan bastırılmıştır. 11.12. yüzyıllarda, ikonoklazmanın etkilerinin tarihe gömüldüğü süreçte, sanat eserlerinin bir kez daha dünyevi kilise ile göksel alem arasında açık paralellikler çizmeye başladığ 1 görülür. Kilise ve cennet alemlerini sıkı bir paralellik içinde birbirine bağlayan ikonografik temaların gelişimi, İkonoklzma sonraki Bizans sanatında görülen yeniliklerindendir (Woodfin, 2010, s. 311). Bu süreci rhipidialarla üzerlerindeki göksel varlıklar üzerinden takip etmek mümkündür.

İkonoklazma dönemi (726-842/843) sonrasında resim sanatındaki değişim ve gelişimine, rhipidionların duvar resimleri üzerinden bakmak mümkündür. Duvar resimlerindeki çağdaş gelişmelerle göksel ve dünyevi ayinler arasındaki çizginin liturjideki örneklerini yansitan rhipidionlar, 13.-15. yüzyıl apsis resim programında, doğum, ölüm, hizmet ve liturji konularıyla ile bağlantılı olarak betimlenmiştir. Rhipidionlar ilgili tasvirler çoğunlukla kutsal bir olan ya da yerlerle ilgilidir. Kiliselerde apsis ve bemadaki pencerelerden gelen doğal güneş ışı̆̆ı bemada sunăg 1 aydınlatmaktadır. Çoğunlukla kiborion altında sunakların yer aldığı bilinmektedir. Bu durum duvar resimlerinde de gösterilmiştir. Duvar resimlerinde sunağın üzerinde figürlerin duruş açılarına gore yerleştirilmiş bir kiborion, altındaki sunakta ise liturjik eşyalar yer almaktadır. Kiborionun kubbesi sembolik açıdan gökyüzünü simgelemekte, altında bazı tasvirlerde görülen güvercinler ise kutsal ruhu işaret etmektedir. Kapadokya Ihlara Vadisi Bezirana Kilise (13. yüzyıl), spsis resim programındaki beyaz güvercin buna örnektir. Sunağın iki yanındaki melek-diyakonların ellerindeki rhipidionlar da bu gerçekliği güçlendirmektedir (Jolivet-Lévy, 2017, s. 115-121, fig. 12).

Kilise duvar resimlerinde en erken uygulamalar 11. yüzyıla tarihlendirilmektedir. Ohrid Ayasofya Kilisesi ve Kiev Ayasofya Kilisesi'nin apsislerindeki Havariler Komünyonu resim programındaki rhipidionlar liturjinin gücünü arttırmak amacıyla uygulanmıştır. İki kompozisyonda komünyon tasvir edilmiştir. Ohrid Ayasofya Kilisesi'nde İsa sunak masasının arkasında bir defa resmedilmiş, Kiev Ayasofya Kilisesi'nde de gösterildiği gibi sunak masasının kenarlarında iki defa resmedilen İsa ile birlikte melek-diyakonlar da iki defa tasvir edilmiştir. İki örnek de bu dönemde başkent İstanbul resim düzeninin uygulanmadığını gösterir. Komünyon teması çerçevesinde değişen uygulamalar görülse de kompozisyonlar, ritüele uygun olarak resmedilmiştir. Komünyon temas1 aracılığıyla tüm ökaristik ayininin uygulamasını yansıtmak amacıyla kasitlı olarak 


\section{Durmuş GÜR - Cahit KARAKÖK}

tasvir edilmiş iki çağdak örnektir. Resim açısından karakteristik olarak, resimsel şemaların farklılığına rağmen, Kiev ve Ohrid Ayasofyalarındaki sahnelerde önemli bir ikonografik yenilik görülür. Sunağın iki yanında tasvir edilen melek-diyakonlar, ellerindeki rhipidionlarla ayine eşlik etmektedir. 11. yüzyıl ile birlikte bu erken uygulamalar, yalnızca göksel kutsallığı belirtmekle kalmaz aynı zamanda, tıpkı bir piskoposun litürjiye katılan rahiplerle iletişim kurması gibi havarilerle sunakta ayrı ayrı iletişim kurarken tüm eylemde tezahür eden İsa'nın Papalık rolünü vurgulamaktadır. Kilisede ayinde bulunan halk, apsiste, sunak üzerindeki resme baktığında, İsa'nın en üstte Baş Rahip olduğu yerde, cennetteki kutsal hiyerarşi fikrini yansitmaktadır (Lidov, 1998b, s. 385). 11. yüzyılda, Kiev Ayasofya Kilisesi ve Ohrid Ayasofya Kilisesi'nin apsislerindeki Havariler Komünyonu'nda melek diyakonların ellerindeki rhipidionlar birbirinden farklı olarak resmedilmiștir (Kriza, 2017, s. 93, 98-99, fig. 1, 5-6). Paleologos döneminde (1259-1453), melek-din adamları hiyerarşisi, melek-diyakonlara ek olarak melek-rahiplerle betimlenmiştir. Mistra Peribleptos Kilisesi'ndeki fresklerde, hem rahip hem de diyakon olarak yetkilendirilmiş melekler tarafindan canlandırılmış büyük giriş tasvir edilmiştir. Ayinde melek-rahipler örtülü kadehler taşırken, melek-diyakonlar, İsa'nın başkanlık ettiği ayinde sunağa ilerlerken başlarının üzerinde örtülü patenleri taşımaktadır. Modern bakış açısıyla bakıldığında ne kadar tuhaf görünse de, duruşlar ve figürlerin tam olarak geç Bizans dönemi öğretileri ile litürjik kitaplardaki gibi şekillendiği görülmektedirr (Woodfin, 2010, s. 313).

İncelenen duvar resimlerinden sadece Misır, Deir el-Syrian Manastırı (13. yüzyılın ilk yarıs1), apsis yarım kubbesindeki rhipidionlar (Snelders and Immerzeel, 2004, s. 117, Pl. 2), yeşil ve kırmızı değerli taşlarla bezenmiştir. 11. yüzyıla tarihlendirilen Ohrid Ayasofya Kilisesi'nin apsisindeki tavus kuşu tüyü tasvirli (üç dişli yaba benzeri) rhipidionlarında da sarı tonlarına sahip olması (Lidov, 1998b, s. 385), 11. yüzyıldan itibaren tasvir edilen rhipidionların özellikle sarı ve sarı tonlarına sahip olduğunu göstermektedir. 13.-15. yüzyıl arasına tarihlendirilen rhipidionların hepsi de sarı ve sarı tonlarına sahiptir. Dini figürlerin başlarındaki haleler ile benzer tonlara sahip rhipidionlar, sarı renkleri ve dini yapılardaki ortak kullanımları kapsamında ele alındığında, sahnenin ikonografik gücünü yansıtmakta, rhipidionun kompozisyondaki liturjik gücünü yansıtmaktadır. Rhipidionlardan bazılarında beyaz incili süslemelere yer verilmiştir. Sırbistan Kara, Beyaz Kilise'de (14. yüzyıl) apsiste, sunağın arkasında, din adamları üzerine rhipidion sallayan üç melek-diyakonun ellerindeki sarı tondaki rhipidionların kenarlarındaki beyaz inci süslemeler, din adamlarının başlarındaki sarı halelerde de görülmektedir. Bu durum rhipidion-hale ile renk-kutsallık ilişkisinin vurgulamak, rhipidionun liturjideki önemini yansıtmak amacıyla yapılmış üslupsal uygulamalardır. Sırbistan, Gračanica Kilise (1321-1322), merkezi kubbede, Göksel Liturji'deki melek-diyakonların ellerindeki rhipidionlar, Riha ve Stumma örneklerinin bordürlerindeki tasvirleri hatırlatmaktadır (Gillette, 2018, s. 33, fig. 3; Betancourt, 2015, s. 497, fig. 5). Burada melek-diyakonların ellerindeki rhipidionların kenarlarında beyaz, dilimli dekoratif bordür, diğer örneklerden tamamen farklı olarak resmedilmiştir. Bu durum liturjinin gücünü göstermenin 


\section{Bizans Sanatında Rhipidion (Flabellum) ve Geç Bizans Dönemi...}

yanında ressam-sanatçı ve bani arasındaki ilişkiyle de açıklanmaktadır. Yunanistan Valsamonero Manastırı, Aziz Phanourios Şapeli (1430-1431), apsisindeki Büyük Giriş (Drandaki, 2017, s. 390-391, fig. 16) kompozisyonunda, rhiha ve stumma örneklerinde olduğu gibi dilimli bordür kullanılmış, Sırbistan, Gračanica Kilise (1321-1322) rhipidionlarından farklı olarak (Gillette, 2018, s. 33, fig. 3; Betancourt, 2015, s. 497, fig. 5) burada bordürler de sar1 olarak tasvir edilmiştir. Ayrıca Yunanistan Valsamonero Manastırı, Aziz Phanourios Şapeli (1430-1431), apsisindeki Büyük Giriş’te rhipidionu taşıyan diyakonun başındaki hale rengiyle diğerlerinden farklı şekilde tasvir edilmiştir (Drandaki, 2017, s. 390-391, fig. 16).

Strbistan Studenica Manastırı, Kral Kilise'de (1314), apsiste Havariler Komünyonu (Gillette, 2018, s. 38, fig. 7), Makedonya Staro Nagoričane, Aziz George Kilisesi'nin (14. yüzy1l), apsisindeki Havariler Komünyonu ve Ihlara Vadisi Bezirana Kilise'de (13. yüzy1l), apsiste tasvir edilen melek-diyakonların ellerindeki rhipidionların çevresindeki beyaz bordür ile sunak çevresinde Ioannes Khrysostomos, Amphilokhios ve Blasios'un halelerindeki beyaz bordürlerin de aynı amaç doğrultusunda resmedildiği görülmektedir (Jolivet-Lévy, 2017, s. 116, fig. 12). Makedonya Lesnova Manastırı'nda (yaklaşık 1342), apsisteki Başrahip İsa'nın Kutsal Eşyaları Kutsaması (Djuric, 2015, s. 130, fig. 1), Sırbistan, Gračanica Kilise (1321-1322), merkezi kubbede, Göksel Liturji (Gillette, 2018, s. 33, fig. 3, Betancourt, 2015, s. 497, fig. 5), Makedonya, Pološko Aziz Georges Kilisesi'nde (1343-1345), Havariler Komünyonu'nda (Popova, 2015, s. 162, fig. 1) ve Romanya, Curtea de Argeş Manastırı'nda (Yaklaşık 1376-1377), prothesiste İsa'nın Ölü Bedeni Başında Melekler (Djuric, 2014, s. 130, fig. 7) kompozisyonlarındaki rhipidionlarla dini figürlerin başındaki haleler sarı, bordürlerinin ise beyaz sunulması, kutsa-renk ilişkisini desteklemektedir. Kapadokya kiliselerinde dekoratif süslemelerden bazıları rhipidion formunda tasvir edilmiştir. Bezirana Kilise'de (13. yüzyıl) naosun köşelerindeki üçgen alanlarda, geometrik şekillerle bezenmiş, alttan yukarıya genişleyen üçgen kesimlerin birleştiği alanlarda madalyonların ortasında seraph benzeri düzenlemeler görülmektedir (Jolivet-Lévy, 2017, s. 123, fig. 21). Özellikle kiliselerin apsis ve bema bölümlerinde resmedilen rhipidionlar, ilahi enerjisinin tezahürüne kozmografik bir boyut kazandırmanın yanında, sembolik meleklerin Tanrı'nın tahtında oturuken yanlarında bulunarak liturjiye öncülük ettiği şeklinde sembolik mesa1 güçlendirmektedir. Kaphiona Aziz Theodores Kilisesi'nin (1263-1264) apsis yarım kubbesinde İsa'nın başı üzerinde büyük bir madalyon ortasında dönen 1şıklı disk yer almaktadır. Göksel çağrışımlarla donatılmış bu disk (Jolivet-Lévy, 2017, s. 125), İsa'nın iki yanındaki Başmeleklerin başlarının hizasında ve eksende yer almasıyla akıllara liturjideki sembolik rhipidionları hatırlatmaktadır. JolivetLévy'nin değerlendirmeleri dışında bazı araştırmacılar, Çarmıhta İsa tasvirlerinin yanlarındaki disk içinde sunulan haçların da rhipidionları sembolize ettiği ifade edilmektedir (Kroos and Wirth, 1991, s. IVC).

14. yüzyıldan itibaren, Havarilerin Komünyonu tasvirlerinde, İsa sunakta ayakta betimlenmiş, üzerindeki antik elbiseler yerini daha zengin giysilere bırakmıştır. Selanik Aziz Nikholas Orphanos Kilisesi (14. yüzyıl) ve Čučer Aziz 


\section{Durmuş GÜR - Cahit KARAKÖK}

Niketas Kilisesi'nde (15. yüzyıl) İsa, ataerkil sakkos ve omophorion giyimli, yardımcısı diyakon ise melek şeklinde giyinmiştir. Makedonya Lesnova Manastırı (yaklaşık 1342), apsisindeki Başrahip İsa'nın Kutsal Eşyaları Kutsaması (Djuric, 2015, s. 130, fig. 1) tasvirinde İsa, sakkos giyimliyken Yunanistan Valsamonero Manastırı'nın narteksinde yer alan Aziz Phanourios Şapeli'nin (1430-1431), apsisindeki İsa (Djuric, 2014, s. 136, fig. 16; Drandaki, 2017, s. 390-391, fig. 16), büyük başrahip şeklinde, mücevherli sakkos giyimli olarak tasvir edilmiştir.

Liturjide resmedilen rhipidionlar, 16. yüzyıl ve sonrasına tarihlendirilen kiliselerin resim programında da yer almaktadır. Athos Dağı'ndaki kiliselerin duvar resimlerinden rhipidionun liturjideki durumunu takip etmek mümkündür. Yunanistan Athos Dağ Dochiariou Manastırı Kilisesi (yaklaşık 1568) apsisi ile Yunanistan Athos Dağı Büyük Lavra, Aziz Nikholas Kilisesi (1560), güney bema duvarında, çeşitli melek-diyakonlar göksel liturjide bulunmaktadır. Göksel klyafetler ve liturjik aletlerle betimlenen sahnede rhipidiononlar yer alır (Betancourt, 2015, s. 503, fig. 8-9). Duvar resimleri daha geç tarihli olmasına rağmen, alayı düzeni ve bileşimi ile 13.-15. yüzyıl duvar resimleriyle benzerlik gösterir. Kıbrıs Palaeokhorio, Transfgurations (Başkalaşım) Kilise (16. yüzyı1), Havarilerin Komünyonu'nda melek-diyakonlar, ellerindeki rhipidionları İsa'nın arkasından sallamaktadır (Stylianou and Stylianou, 1997, fig. 169-170), Kıbris, Podithou Panagia Kilise, Havarilerin Komünyonu'nda, İsa kuzey ve güneyde, iki ayrı kiborion içinde melek-diyakon ile tasvir edilmiştir. Kuzeyde, kiborionun dışında yer alan sunak üzerideki ekmeği Petrus'a sunan İsa ile güneydeki kiborion içinde melek-diyakon ile tasvir edilen İsa, elindeki çift kulplu kaptan Pavlus'da şarap sunar. Kiborionun içinde ve İsa'nın arkasında yer alan melek-diyakonun, İsa'nın arkasından salladığı rhipidionda seraph tasvir edilmiştir. Rhipidionlar burada seraph gibi tasvir edilmiş çevresinde herhangi bir madalyon bulunmamaktadır (Stylianou and Stylianou, 1997, fig. 46-47). Bu tasvirler, erken Bizans döneminden itibaren küçük el sanatlarında görmeye alıştığımız ve zamanla liturjinin parçası haline gelen rhipidionların, 12. yüzyıl sonrasında duvar resimlerinde büyük öneme sahip olduğunu, 13.-15. yüzyıl arasında büyük bir atak halinede kiliselerdeki Havariler Komünyonu tasvirlerinde öne çıktığını göstermektedir. Bununla da sinırlı kalmayan duvar resmi örnekleri 16. yüzyıl ve sonrasındaki kiliselerde de aynı düzende resmedilmeye, izleyenleri etkilemeye devam etmiştir.

Aziz Clementine (4. yüzyıl sonu) ve Ruspe Piskoposu Fulgentius'un (468533 ya da 462-527), öğrencilik günlerinde kullandığı bilinmesine rağmen teolojik açıdan nasıl kullanıldığı bilinmeyen bu ilk örneklerin 9. yüzyıla kadar gelişim gösterdiği ve İkonoklasmus dönemi (726-842/843) sonrasında kiliselerde liturjinin vazgeçilmez bir parçası haline geldiği ortadadır. Kiliselerde rhipidionların tasvirlerinin gelişmesi ve bunların hayranlarının sembolizmi geliştikçe, litürjik kullanımlarının da gelişme gösterdiği belirlenmiştir. Diyakonların denetiminde liturjide kullanılan rhipidionların 13.-15. yüzyıllarda, ayin eylemleri sırasında meleklerin görünmez varlığını sembolize ettiği bilinir. Cherubikon eşliğinde büyük girişte daha çok görkemli örnekleri kullanılan rhipidionların, yüzeylerindeki 


\section{Bizans Sanatında Rhipidion (Flabellum) ve Geç Bizans Dönemi...}

kherub-seraph benzeri tasvirler, erken Bizans dönemi liturjik eşyaların yüzeylerindeki uygulamaları hatırlatır. Mistik bir şekilde kherubları temsil eden ve liturjiye güç katan ilahiler eşliğinde sunak çevresinde sallanan rhipidionlar, Tanrı'nın tahtının varlığını görüşünü güçlendirmekle birlikte göksel varlıkların olaya tanık olduğunu hissettirmektedir. Bu durum duvar resimleriyle kalıcı hale getirilmiş, her an yapıyı ziyaret edenlere liturjinin etkisi sunulmuştur. İncelemelerimiz sırasında özellikle 13.-15. yüzyıllara tarihlendirilen kilise duvar resimlerinde; sıklıkla liturji (büyük giriş ve küçük giriş), Havarilerin Komünyonu, Koimesis Meryem (Meryem'in Ölümü) ve Hetoimesia (Boş Taht) tasvirlerinde ellerinde rhipidionlarla melek-diyakonların tasvir edildiği belirlenmiştir. Erken Bizans döneminde metinlerde anlatıldığı gibi sunak çevresinde melekler gibi giyinen diyakonların 13.-15. yüzyıl örneklerinde melek-diyakon olarak tasvir edilmesi, bu durumun liturjik olarak geç Bizans dönemine kadar devam ettiğini duvar resimleri üzerinden göstermektedir. Kısaca özetlemek gerekirse, Tanrı’ya duyulan saygının rhipidion ve üzerindeki göksel sembollerle yansıtmanın büyük öneme sahip olduğu, 11. yüzyıldan itibaren duvar resimlerinde görülen rhipidionların, 13.-15. yüzyllardaki dini-liturjik resim programında üslup ve ikonografik açılardan gelişme göstererek resmedildiğini belirtmek mümkündür.

\section{KAYNAKÇA}

ACARA, M. (1998). Bizans Ortodoks Kilisesinde Liturji ve Liturjik Eserler. Hacettepe Üniversitesi Edebiyat Fakültesi Dergisi, Cilt, 15, Say1, 1, Ankara, 183-201.

ACARA-ESER, M. (2020). Bizans Maden Sanat,, Dini Törenlerde Kullantlan (Liturjik) Eşyalar. Ankara: Bilgin Yayınları.

AKYÜREK, E. (1996). Bizans'ta Sanat ve Ritüel. İstanbul: Kabalcı Yayınevi.

BALLIAN, A. (2004). Liturgical Implements. Byzantium: Faith and Power (1261-1557), (Edit.: H. C. Evans). New York, 132-133.

BETANCOURT, R. (2015). The Thessaloniki Epitaphios: Notes on Use and Context May. Greek, Roman and Byzantine Studies, 55(2), 489-535.

DIMITROVA, E. (2015). The Church of Saint Panteleimon at Nerezi. Skopje: Office for Protection of Cultural Heritage.

DOĞAN, S. \& ÜNSER, Ş. (2011). Bizans Sanatında Kherub ve Seraph İmgeleri. Anadolu Kültüründe Süreklilik ve Değişim, Dr. A. Mine Kadiroğlu’na Armăgan (Edit.: A. Ceren Erel, Bülent İşler, Nilüfer Peker, Güner Sağır). Ankara. 199-218.

DJURIC, M. T. (2014). To Picture and to Perform: The Image of the Eucharistic Liturgy at Markov Manastir (I). Zograf, 38, 123-141.

DJURIC, M. T. (2015). To Picture and to Perform. The Image of the Eucharistic Liturgy at Markov Manastir (II). Zograf, 39, 129-149.

DRANDAKI, A. (2017). Piety, Politics, and Art in Fifteenth-Century Venetian Crete. Dumbarton Oaks Papers, 71, 367-406.

GERSTEL, S. E. J., KYRIAKAKIS, C., ANTONOPOULOS, S., RAPTIS, K. T. \& DONAHUE, J. (2021). Holy, Holy, Holy: Hearing the Voices of Angels. Gesta, Vol.: 60 (1), 31-49.

GILlETTE, A. (2018). The Music of Angels in Byzantine and Post-Byzantine Art. Journal of Medieval Art and Architecture, 6 (4). 26-78.

GKIOLES, N. and PALLIS, G. (2014). Atlas of the Christian Monuments of the Aegean From the Early Christian Years to the Fall of Constantinople (Edit.: Nikolaos 


\section{Durmuş GÜR - Cahit KARAKÖK}

Gkioles ve Giorgos Pallis). Athens: General Secretariat of the Aegean \& Island Policy.

GREEN, R. B. (1951). The Flabellum of Hohenbourg. The Art Bulletin, 33 (3), 153-155.

GREENWOOD, T. (2015). A Corpus of Early Medieval Armenian Silver. Dumbarton Oaks Papers, Vol.: 69, Washington, 115-146.

JOLIVET-LÉVY, C. (2012). Militaires et Donation en Cappadoce (IXe -XIe siècle). Donation et Donateurs Dans le Monde Byzantin, Réalités Byzantines, Vol.: 14, Paris. 141-161.

JOLIVET-LÉVY, C. (2017). Bezirana Kilisesi (Cappadoce). Un Exceptionnel Décor Paléologue en Terres de Rūm. Nouveau Témoignage sur les Relations Entre Byzance et le Sultanat. ЗОГРАФ, Vol.: 41. 107-142.

KESSLER, H. L. (2012). Images Borne Ona Breeze: The Function of the Flabellum of Tournus as Meaning. Charlemagne et Les Objets. 1-22.

KRIZA, A. (2017). Visualizing a New Orthodox Identity: The Sanctuary Decorations of the Sophia Churches in Ohrid and Kiev. Mount Athos-the Light of the Orthodox Christianity: Interaction of Cultures International Conference (Post Prints 5-7 October 2016). 91-105.

KROOS, R. \& WIRTH, K. (1991). Flabellum. RDK, IX, 428-507. https://www.rdklabor.de/wiki/Flabellum (und Scheibenkreuz)

LIDOV, A. (1998a). Heavenly Jerusalem: The Byzantine Approach. Jewish Art, Vol.: 23/24 (1997/1998). 340-353.

LIDOV, A. (1998b). "Byzantine Church Decoration and the Great Schism of 1054", Byzantion, Vol.: 68 / No.: 2. 381-405.

MANGO, C. (1962). Materials for the Study of the Mosaics of St. Sophia at Istanbul. Dumbarton Oaks Research Library and Collection.

MANGO, M. M. (1991). Rhipidion. Oxford Dictionary of Byzantium, I.II.III (Edit: Alexander Kazhdan), Oxford. 1790-1791.

MEYENDORFF, P. (1984). On the Divine Liturgy, St. Germanus of Constantinople. New York: St. Viladimir's Press.

PENTCHEVA, B. V. (2014). Mirror, Inspiration, and the Making of Art in Byzantium. Exchanges and Interactions in the Arts of Medieval Europe, Byzantium, and the Mediterranean, CONVIVIUM, I, II. Université de Lausanne-Academy of Sciences of the Czech Republic-Masaryk University, 10-39.

PENTCHEVA, B. V. (2016). Liturgy and Music at Hagia Sophia. Oxford Research Encyclopaedia. 1-27.

POPOVA, A. (2015). The Representation of Christ as the Great Archpriest and King in the Decoration of St. Georges at Pološko. Patrimonium, 10, 161-170.

RHEAD, G. W. (1910). History of the Fan. London: Kegal Paul, Trench, Trübner \& Co. Ltd.

ŠAKOTA, M. (2004). Rhipidion. Byzantium: Faith and Power (1261-1557). New York: Metropolitan Museum of Art. 133-134.

SCHROEDER, R. B. (2008). Images of Christ Emmanuel in Karanlık Kilise. Studies in Iconography, Vol.: 29. 23-54.

SNELDERS, B. \& IMMERZEEL, M. (2004). The Thirteenth-Century Flabellum from Deir al-Surian in the Musée Royal de Mariemont (Morlanwelz, Belgium). ECA, 1. 113139.

STYliAnOU, A. \& STYLIANOU, J. A. (1997). The Painted Churches of Cyprus. Cyprus: A.G. Leventis Foundation. 


\section{Bizans Sanatında Rhipidion (Flabellum) ve Geç Bizans Dönemi...}

TRIBE, S. (2018). A Brief History of the Flabellum. Liturgical Arts Journal, 1. https://www.liturgicalartsjournal.com/2018/07/a-brief-history-of-flabellum.html

VASILESKI, A. (2016). The Most Significant Values of the Cultural and Natural Heritage. Skopje: The Monastery of Treskavec.

VIKAN, G. (1979). Rhipidion With Tetramorph. Age of Spirituality: Late Antique and Early Christian Art, Third to Seventh Century (Edit.: Kurt Weitzmann). New York: The Metropolitan Museum of Art. 617-618.

VON FÜRSTENBERG, M. F. (1979). Das Flabellum in der Kirche des Westens. Westfälische Zeitschrift, 129, 157-192.

WESSEL, K. (1971). Flabellum. Reallexikon Zur Byzantinischen Kunst, Band: II. Stuttgart: Anton Hiersemann. 550-555.

WOODFIN, W. T. (2010). Celestial Hierarchies and Earthly Hiearchies in the Art of the Byzantine Church. The Byzantine World (Edit.: Paul Stephenson). 303-319.

WOODFIN, W. T. (2015). Disjuncture between Text and Image: Mystagogy and the Embroidered Iconography of Byzantine Vestments. Clothing the Sacred. Medieval Textiles as Fabric, Form, and Metaphor, Textile Studies 8 (Edit.: Mateusz Kapustka and Warren T. Woodfin). Berlin. 13-32. 